NBER WORKING PAPER SERIES

\title{
WINDOW DRESSING IN THE PUBLIC SECTOR: \\ A CASE STUDY OF CHINA'S COMPULSORY EDUCATION PROMOTION PROGRAM
}

\author{
Hanming Fang \\ Chang Liu \\ Li-An Zhou \\ Working Paper 27628 \\ http://www.nber.org/papers/w27628
NATIONAL BUREAU OF ECONOMIC RESEARCH
1050 Massachusetts Avenue
Cambridge, MA 02138
July 2020

We thank seminar participants at Princeton University, Penn-UCSD Conference on Chinese Political Economy, and Peking University for valuable comments and suggestions. All errors remain ours. The views expressed herein are those of the authors and do not necessarily reflect the views of the National Bureau of Economic Research.

NBER working papers are circulated for discussion and comment purposes. They have not been peer-reviewed or been subject to the review by the NBER Board of Directors that accompanies official NBER publications.

(C) 2020 by Hanming Fang, Chang Liu, and Li-An Zhou. All rights reserved. Short sections of text, not to exceed two paragraphs, may be quoted without explicit permission provided that full credit, including (C) notice, is given to the source. 
Window Dressing in the Public Sector: A Case Study of China's Compulsory Education Promotion Program

Hanming Fang, Chang Liu, and Li-An Zhou

NBER Working Paper No. 27628

July 2020

JEL No. D73,H11,H41,P26

\section{ABSTRACT}

We examine window dressing phenomenon in the public sector by studying the strategic responses of Chinese local officials to the compulsory education promotion program launched by the central government in the 1990s. According to this program, the Chinese counties should receive inspections on whether the compulsory educational targets were achieved on prescheduled time by provincial governments; and failing to pass the inspection would have severe negative career consequences for the county leaders. We find that county-level educational expenditures saw a sustained increase before the inspection, but a sharp drop immediately after the inspection. Local officials who were more likely to be inspected within their tenures windowdressed more aggressively. As a result, middle school enrollment rates declined significantly after the inspection, and rural girls bore the blunt of the decline in school enrollment.

Hanming Fang

Department of Economics

Ronald O. Perelman Center

for Political Science and Economics

133 South 36th Street

Suite 150

Philadelphia, PA 19104

and NBER

hanming.fang@econ.upenn.edu

Chang Liu

Renmin University of China

National Academy of Development and Strategy

CHINA

liuchanggsm@163.com
Li-An Zhou

Guanghua School of Management

Peking University

Beijing 100871

CHINA

zhoula@gsm.pku.edu.cn 


\section{Introduction}

Window dressing is a common strategic reaction to incentive schemes observed in various types of organizations. In the corporate world, firm accountants use creative ways, e.g., postponing paying suppliers to create a higher period-end cash balance, to improve the appearance of financial statements; bond managers usually manipulate their portfolio holdings to impress investors at certain high-stake time nodes. Window dressing is also widespread in the public sector of both developed and developing countries. Bureaucrats strategically take actions to appease voters and/or upper-level government officials. For example, in UK there were accusations that the small business support was "nothing but window-dressing"; 1 in India the Union Interim Budget in 2019 was accused of "fiscal window dressing" to appease the electorate according to the policy observers. ${ }^{2}$ In stark contrast with the well-documented evidence in corporate finance and accounting literature (e.g., Lakonishok et al., 1991; Agarwal et al., 2014), the window dressing phenomenon in the public sector, which may involve more sizable resource misallocations, has received scant attention in the economic literature. A lack of systematic analyses in this regard is mainly caused by the empirical challenge of finding an appropriate setting to identify the government's window dressing behavior.

In this paper, we provide an empirical analysis of the window dressing behavior in the public sector by studying the strategic responses of local governments to China's compulsory education promotion program in the 1990s. In 1993, the Chinese central government launched a national goal of essentially achieving the nine-year compulsory education and eliminating illiteracy among young and middle-aged adults by 2000. To fulfill this goal, each county should reach specific targets on a number of key educational performance indicators, namely, the primary and middle school enrollment and dropout rates, by pre-specified, county-specific deadlines. Subsequently, each county should receive a one-time inspection from the provincial government before the pre-specified deadline set by the provincial government. As will be

\footnotetext{
${ }^{1}$ Business Link: Small business support is 'nothing but window dressing', says former Government advisor, by Stuart Pearcey, May 15, 2019. https://www.runagood.com/press/small-business-support-is-nothing-butwindow-dressing-says-former-government-advisor.

${ }^{2}$ The Hindu Business Line: An exercise in fiscal window-dressing, by RK Pattnaik, February 5, 2019. https://www.thehindubusinessline.com/opinion/fiscal-prudence-goes-for-a-toss/article26186225.ece. A similar media report about window dressing phenomenon in Thailand's public sector can be found in https://www.bangkokpost.com/thailand/politics/1702432/govt-reform-push-window-dressing. 
detailed later, fulfilling the compulsory education targets posed a mounting financial challenge for most counties in China during the 1990s; even worse, local leaders who had authority over the allocation of fiscal resources typically lacked incentives to invest in compulsory education since their career advancement had been closely linked with local economic growth (Li and Zhou, 2005; Xu, 2011; Yao and Zhang, 2015) rather than local educational outcomes. To incentivize the enforcement of compulsory education targets, the central government imposed strict rules on the promotion of county leaders: if they failed to accomplish the compulsory education targets before the deadlines, they would lose any chance of promotion for a period of time, or could even be sacked from their current positions. However, once a county had successfully passed the inspection, there was no extra reward for over-fulfillment, and there were no further inspections from the upper-level governments. Such an institutional setting generated strong incentives for county leaders to window dress by mobilizing all possible resources to meet the targets before the deadline, but then slacking off after passing the inspection.

Exploiting the precise information on the pre-specified timing of inspections for all counties during the period of 1993-2001, we apply an event study analysis of the county-level educational expenditures of different types, the rural educational surcharges, and the school enrollment rates before and after inspections. We find that county-level educational expenditures saw a sustained increase before the inspection; but the educational expenditures and middle school enrollment rates decreased significantly immediately after inspections. Our estimates show that once a county passed the inspection, its once-increasing total educational expenditures before the inspection quickly decreased by nine percent, and the reduction appeared to be especially salient for those discretionary educational expenditure categories that are mostly funded by surcharges on local firms and peasants. Further analysis suggests that the drop of educational expenditures was mainly driven by the operating expenses of compulsory schools which were relatively flexible for adjustments, while the inelastic personnel expenditures per pupil exhibited no signs of significant changes. The educational surcharge rate on peasants dropped considerably as well after the inspection. These pieces of evidence together suggest that county leaders tried very hard to mobilize financial resources, even 
leveraging the surcharges on peasants, to reach the compulsory education targets; however, they slacked off immediately after passing the inspections. These results lend support to the window-dressing hypothesis.

We further explore the role of political incentives in driving the window dressing phenomenon among local government leaders. First, we show that a county's pre-specified inspection time was orthogonal to the inauguration of its party secretary, who has the final authority within his/her jurisdiction over the allocation of public resources. This evidence confirms the pre-determined nature of the inspection time, which was set by the provincial superiors, and alleviates the concern about the endogeneity of county leaders' tenures. Second, we find that when the inauguration year drew closer to the inspection year, ceteris paribus, the increase in county educational expenditures becomes significantly higher. Our estimate indicates that if the party secretary took office just one year earlier than the inspection year, the educational expenditure would increase by about $4 \%$ compared to the benchmark level of the control group of local leaders who took their office after the inspection. This pattern is consistent with our window dressing hypothesis because when the time interval between the inauguration and the inspection is shorter, the pressure to meet the compulsory education target is likely to be more intense, therefore the response from the party secretary to the pre-scheduled inspection is more aggressive in the hope of avoiding the severe consequences of political punishment.

We also provide evidence that local governments' window-dressing behaviors have severe consequences: after the inspection, there was a significant one-percentage-point decline in the middle school enrollment rates; moreover, the deterioration in school enrollment generated distributional consequences since rural girls bore the blunt of the decline in middle school enrollment rates.

This paper is related to several strands of literature. The first strand of literature examines the window-dressing behaviors in corporations (e.g., Lakonishok et al., 1991; Allen and Saunders, 1992; Agarwal et al., 2014). Compared to such a large body of literature documenting window dressing behaviors of firms or fund managers, the analysis of the public 
sector is still in its infancy. ${ }^{3}$ To the best of our knowledge, we are among the first empirical attempts to systematically study the window dressing phenomenon in the public sector.

This paper is also closely related to a burgeoning literature on how incentive schemes in the form of pre-specified targets or deadlines distort agents' efforts across time in hierarchical organizations. In a seminal paper, Oyer (1998) explores the consequences of sales targets on the timing of revenues as well as contractual prices. Courty and Marschke $(1997,2004)$ study how local job-training centers strategically reported their performance outcomes to maximize the rewards in the context of the Job Training Partnership Act of 1982 in the United States. Building on these initial efforts, several scholars studied the welfare implications of resource misallocation across various contexts. For example, Liebman and Mahoney (2017) unpack the fact that the budget expiration at the end of a fiscal year may incentivize the US federal government to rush to spend money on low-quality projects. In a similar vein, Cao et al. (2018) study the consequences of Chinese banks' end-of-month increase of loans and find that the incremental loans made to hit the loan targets are $26 \%$ more likely to eventually turn into nonperforming loans.

Our study also contributes to the political economy literature on upward accountability in authoritarian countries (Smith, 1991), and local accountability in developing countries (Bardhan and Mookherjee, 2000, 2005, 2006; Alatas et al., 2019; Ferraz and Finan, 2011; Finan et al., 2017). In authoritarian countries, such as China, local governments allocate resources guided by the administrative orders from their higher authorities. The distinct institutional background of China's compulsory education promotion program provides a valuable setting to examine the strategic reactions of China's local governments to the strict orders from the upper-level government and their consequences.

The evidence we document in this study suggests that using top-down inspections together with political discipline in bureaucracies can backfire. In this regard, our study complements the literature highlighting the distortionary consequences of using high-powered incentives in the public sector (Banerjee et al., 2008; Fisman and Wang, 2017; Acemoglu et al., forthcoming). Our study also sheds light on how Chinese county leaders' political incentives affect the

\footnotetext{
3 A rather small theoretical literature, which spans several social science disciplines, has conducted preliminary analyses of the window dressing phenomenon in the public sector (e.g., Bischoff and Blaeschke, 2016).
} 
provision of local public goods in education and thus relates to similar studies in other contexts of China, such as environment protection (Jia, 2017; He et al., 2020; Greenstone et al., 2020) and workplace safety (Fisman and Wang, 2015, 2017; Shi and Xi, 2018). ${ }^{4}$

Finally, our paper relates to the growing literature on identifying short-termism in political organizations. The theoretical literature on organizations has long recognized the existence of short-termism of agents with career concerns facing the multitasking problem (Holmstrom and Milgrom, 1991; Garicano and Rayo, 2016). Xiong (2018) incorporates Chinese local officials' career concerns into a macro growth model and rationalizes how short-termism behavior (e.g., over-reporting of GDP and excessive leverage) arises. The insights provided by our study highlight that top-down inspection aided by high-powered career incentives can introduce short-termism behavior in hierarchical bureaucratic systems.

The rest of this paper proceeds as follows. In Section 2, we introduce the background of China's compulsory education promotion and inspection policy. In Section 3, we describe our data and lay out the empirical framework. In Section 4, we document local governments' window dressing behavior on educational inputs. In Section 5, we examine the effects of the local leaders' political career incentives. In Section 6, we look at the consequences of the policy on school enrollment rates. In Section 7, we conclude.

\section{China's Compulsory Education Promotion Program}

\subsection{The Enactment of Compulsory Education and its Enforcement}

The initial education level of the Chinese population was low. In 1982, only about onethird of Chinese adults had a middle school or above literacy. ${ }^{5}$ To improve the educational attainment of the population, China enacted its Compulsory Schooling Law in 1986. According to this law, all Chinese citizens should fulfill nine-year compulsory education. However, despite the backing of the national legislature, the mandatory compulsory schooling policy only achieved limited progress in subsequent years. In 1990, for instance, the overall enrollment

\footnotetext{
4 A large strand of empirical literature emphasizes the critical role of China's tournament-style political meritocracy (Li and Zhou, 2005; Jia et al., 2015; Yao and Zhang, 2015) as well as its distortionary effects on local officials' behavior (e.g., Chen et al., 2017; Jia, 2017; Wang et al., 2019). See Xu (2011) for an extensive literature review.

5 Data source: China's 1982 population census.
} 
rates for primary school and middle school were $97.8 \%$ and less than $70 \%$, respectively. Both failed to live up to the requirements of the compulsory schooling mandate, and the gap was especially large for middle school enrollment rates. There are at least two reasons for the slow progress. First, counties bore an overwhelming share of the financial responsibility for fulfilling the compulsory schooling mandates. In the later 1980s and early 1990s, a large number of counties faced severe financial constraints due to their underdeveloped local economies, especially for counties in China's interior regions. Second, local officials who held the authority to allocate fiscal funds cared more about local economic development than education since their promotion was closely linked to local economic performance, but not to improvement in educational outcomes ( $\mathrm{Li}$ and Zhou, 2005; Xu, 2011). Therefore, local officials with limited tenure generally lacked incentives to allocate already limited financial resources to compulsory education, which would bear fruit in the long run for the local economy but contribute little to the local officials' promotion. ${ }^{6}$

The Chinese central government realized the problem of the lack of local political incentives and made an important move. In 1992, Jiang Zemin, the then General Secretary of the Chinese Communist Party (CCP), proclaimed solemnly in the $14^{\text {th }}$ National Congress of the CCP that China would reach the goals of making nine-year compulsory education generally available and eliminating illiteracy among young and middle-aged adults by $2000 .{ }^{7}$ This announcement sent two important messages to China's local officials: first, the accomplishment of the compulsory schooling now turned into be a necessity for local governments since the top leader of the CCP already made the commitment to both domestic and international communities; second, the implementation of the compulsory education would now have a binding timeline. Right after Jiang's speech, the CCP Central Committee and the State Council jointly released a guideline titled Chinese Educational Reform and Development Compendium in 1993, which was shortly followed by the detailed action plans drafted by the Ministry of Education. The national goals were decomposed into specific targets for each province, which were further decomposed into the ones for each county, together with a

\footnotetext{
${ }^{6}$ According to the dataset we collected for county party secretaries in office in 1993-2000, their average tenure was 3.54 years.

7 At the national level, "generally available" was defined as covering over $85 \%$ of the whole population. 
detailed timeline for enforcement and inspection. The Ministry of Education also established a clear-cut package of specific performance targets for the inspection. The key performance indicators include four aspects:

1. The enrollment rate for children of primary-school-age should be $100 \%$. The enrollment rate for children of middle-school age should be above 95\%;

2. The dropout rate of primary school should be around 1\%; the dropout rate of middle school should be below 2\% in urban areas and below 3\% in rural areas;

3. The growth rate of fiscal education appropriations should exceed the growth rate of fiscal revenue. Personnel and operating education expenditures per-pupil should increase year by year and reach the minimum standard set by the provincial government;

4. The educational facilities and teachers' quality should achieve the minimum standard set by the provincial government.

Among the above requirements, the first two regarding school enrollment and dropout rates were most crucial for inspection and evaluation. A county fulfilling these requirements would be awarded the status of Certified Compulsory Education County (CCEC). To avoid potential fraud and data manipulation by county governments, the central government mandated a procedure of inspection and appraisal to monitor and check the target fulfillment. Notably, the procedure took the following steps. First, the county government should make sure that the specified targets for promoting compulsory education be satisfied and then "applied for" superiors' inspection before the deadline pre-specified by the provincial government. Next, the provincial government would send inspectors on-site to verify whether the county was qualified for being awarded a certificate of CCEC. Upon verification, the provincial government would report the results of inspection and verification to the Ministry of Education for reexamination. When the Ministry of Education certified the report, this applicant county would be awarded the CCEC title, and its certified status would be released to the public.

The large regional disparity in economic conditions across China necessitated that the central government allowed different regions to achieve the compulsory education targets at different time. In 1993, the Ministry of Education drafted a multi-stage action plan in which the timeline of fulfillment reflected the variations in regional development levels. The general 
principle was that cities and counties with better economic and educational endowments should achieve their targets and receive inspections earlier. About 200 remote and poor counties were explicitly granted a delay in their inspections and certifications beyond 2001. Each province followed the guidance of the Ministry of Education to design a sequence of inspection and certification in its jurisdiction in accordance with the characteristics of all applicable counties. Once this sequence was finalized, every county could not renegotiate the deadline with its provincial superior and had to "apply for" inspection before it.

From 1993 to 1994, a total of 554 counties (or city districts) across 27 provinces received inspections for their fulfillment of compulsory education targets. More and more counties joined in as time went on. The list of the CCECs was announced on an annual basis. Figure 1 displays the fraction of approved CCECs by year. At the end of 2000, China's central government claimed great success in the compulsory education promotion program. ${ }^{8}$ During the entire process, every county applying for inspection received the CCEC title with no exception. This is not hard to understand: only when it felt very sure about the achievement of compulsory education targets would a county apply for inspection. Otherwise, a failed evaluation amounted to a political "suicide" for county leaders.

[Figure 1 About Here]

Probably due to the change of top leadership from Jiang Zemin to Hu Jintao in 2002, and a resulting shift of national priorities, the compulsory education promotion program was no longer treated as a top priority from 2002 on. Therefore, our analysis focuses on the period 1993-2001. Another reason for imposing this restriction is that the data on county-level educational expenditures and their subcategories are not available after 2001. Figure 2 illustrates the spatial distribution of counties passing the inspection and receiving the CCECs status year by year from 1993 to 2001 .

[Figure 2 About Here]

\subsection{The Financial Challenges of Compulsory Education for County Governments}

It is worth mentioning that the accomplishment of the nine-year compulsory schooling

\footnotetext{
${ }^{8}$ Since the remaining non-CCECs were all located in the economically underdeveloped regions, the progress became somewhat slower than before. It took China another eleven years to announce the final and complete fulfillment of compulsory education goals in 2011.
} 
posed severe financial challenges for a majority of counties in the 1990 s and early 2000 s, especially in the interior regions of China. After the new initiative was launched in 1992, the financial burden for compulsory schooling was born by the county governments. One particular difficulty laid in how to raise the middle-school enrollment from around 78\% in 1993 to $95 \%$. In the mid-1990s, a 17\% increase of middle-school enrollment for a typical county implied that it should accommodate nearly 2,800 more students into junior middle schools for each birth cohort, or 8,400 more students for the entire junior middle schools with a 3-year curriculum. Based on the data on the educational expenditure per-pupil (670 RMB) in the mid-1990s, such an increase in enrollment would require that the county increase its education expenditures by about 5.628 million $\operatorname{RMB}(2,800 * 670 * 3)$ every year, which accounted for about $4.7 \%$ of the annual budgetary expenditure of an average county. This budgetary increase was not an easy job for a typical county government; also note that above back-of-the-envelope calculations are very conservative since we do not account for the additional expenditures on the construction of school buildings needed to accommodate the large increases in enrollment.

The total educational expenditures of a county consisted of two parts: fiscal educational expenditures and non-fiscal expenditures. The fiscal educational expenditures were usually financed by taxation and intergovernmental transfer payments from higher-level governments. In China, the types of taxes, as well as their bases and rates, are all set up by the central government. Since the tax-sharing reform in 1993, the central government had commanded 5060 percent of tax revenues. For instance, in our sample period of 1993-2001, seventy-five percent of value-added tax, the largest source of tax revenues in China, went to the central government, and local governments retained only twenty-five percent. Twenty-five percent of value-added taxes would be shared further by provincial, prefectural, and county governments (Lou and Wang, 2007). Since county governments took primary responsibility for compulsory education, the earmarked transfer payments from higher-level governments were minimal. Unless the counties enjoyed a vibrant and developed local economy, the fiscal expenditures on education faced fairly tight constraints for most counties.

The second part, the non-fiscal expenditures on education, came from funds collected from fees and surcharges for educational purposes paid by local firms and peasants. To seek 
additional funding sources for educational expenditures, local governments introduced semimandatory fees and surcharges in the 1990s, some of which received no authorization from the central government. Local firms and peasants were urged to pay surcharges to raise local educational funds. The surcharge rate was mostly determined in an ad hoc fashion by county governments. ${ }^{9}$ Due to the discretionary nature and lack of regulation from higher-level governments, non-fiscal funds had become an important source of financing for the county governments whenever they faced increasing fiscal pressures, but excessive extraction from local firms and peasants would also result in complaints that could jeopardize the local leaders' careers.

\subsection{Political Discipline Imposed on Local Leaders and Their Strategic Reactions}

Local officials needed to compete against their political peers for better economic growth, as a result they typically had poor incentives for improving education. In the absence of additional pressure, local officials would squeeze educational expenditure and shift resources to projects that could quickly boost economic growth to improve their chances of promotion.

The lack of political incentives for local leaders in promoting compulsory education was one of the key obstacles for the limited progress in fulfilling compulsory education during the late 1980s and early 1990s. In 1993, the central government took new measures to remedy the lack of political incentives. The most notable one was the explicit stipulation that county leaders should take primary responsibility for policy enforcement and evaluation to fulfill the compulsory education targets, and failing to reach the target on the pre-specified date would disqualify the county leaders (both party secretary and mayor) from any chance of promotion for a period of time regardless of how well they perform in other tasks. This is referred to as "one-item-veto" (yi piao fou jue in Chinese), and it served as an important supplement to the promotion tournament that had so far emphasized local economic growth. ${ }^{10}$ Under this scheme, over-fulfilling the specified tasks would not help local leaders' career advancement, but an

\footnotetext{
9 Apart from paying fees and surcharges, peasants sometimes had to donate free labor for constructing school facilities in rural areas, which did not show up in the non-fiscal expenditures.

10 Similar incentives were also applied to achieve goals in other social responsibilities of local governments, such as birth control, social stability, and recently, environmental protection. Workplace safety was recently added to the list of "one-item-veto" areas for local government officials. See Fisman and Wang (2016) for a study of "death ceilings" in China's working place safety management.
} 
under-fulfillment would cause severe career consequences.

The imposition of the "one-item-veto" system placed local officials in a tough tradeoff between the daunting task of fulfilling the compulsory education and the necessity of meeting the deadline set up by the provincial superiors. A rational strategy for county leaders to react to this tradeoff is to temporarily mobilize and reallocate resources across categories and over time to reach the minimum targets. By resource mobilization and reallocation across categories, we mean that county governments would manage to increase educational expenditures, especially through leveraging discretionary non-fiscal resources (such as increased levies on fees and surcharges) or even shifting expenditures from non-education purposes to educational purposes. By resource reallocation over time, we mean that once the compulsory education targets are achieved before the deadline, the resources temporarily reallocated to education would revert to their original purposes, and the unpopular educational surcharges on local firms and peasants would also be lifted. All these reallocations would result in a sharp decrease in education expenditure immediately after the completion of the inspection, and the educational performances (such as school enrollment) would also deteriorate immediately and even fall below the original targets. We define these activities of resource mobilization/reallocation across categories and over time as the window-dressing behaviors of local leaders in response to their superiors' inspection. There is abundant anecdotal evidence that county leaders adopted the "window-dressing" strategy to deal with the inspection and evaluation of compulsory education. ${ }^{11}$ But so far, there has been no systematic investigation of the window-dressing behaviors in China's compulsory education promotion program, which is the focus of our subsequent analyses.

\section{Empirical Methodology}

\subsection{Data}

We construct a comprehensive dataset for 2,060 Chinese counties, covering the main period of the program from 1993 to $2001 .{ }^{12}$ In our analyses, we exclude all counties in Tibet

\footnotetext{
${ }^{11}$ For example, International Herald Tribune: A Survey on the Fraud of Compulsory School Dropout Rate, 2005-1-25, Website: http://news.sina.com.cn/e/2005-01-25/12195662198.shtml.

12 Our empirical analysis focuses on the period 1993-2001 because detailed county-level educational
} 
and four provincial-level municipalities (Beijing, Tianjin, Shanghai, and Chongqing) due to their special status in China, as well as all city districts due to data availability constraints. ${ }^{13}$ Next, we describe our main variables and data sources in detail.

County-level information. We collect the inspection year for each county from various years of China's Education Yearbook to construct our main regressor. To aid our analyses, we consider several crucial time-invariant county attributes. First, we calculate a county's average elevation and average slope using the Digital Elevation Model (DEM). The county-level geographic information used in this paper comes from China's National Geographic Information System (CNGIS). Second, we assess the proportion of citizens with primary school or above literacy, the proportion of citizens with middle school or above literacy, and the illiteracy rate from China's 1990 population census. Third, we collect information on whether a county was defined as a minority county or a National Poor County from China's National Bureau of Statistics (NBS).

Educational inputs. We collect a rich set of educational input measurements from various years of China's Education Expenditure Yearbook, including total education expenditure, fiscal education expenditure, non-fiscal education expenditure, rural educational surcharge rate (measured by the proportion of rural educational surcharges in per capita rural income), and per-pupil school expenditures, separately for primary and middle schools. It is noteworthy that all of the educational input outcomes used in this paper exclude infrastructure construction expenditures, which are funded through separate appropriations according to China's fiscal system. The per-pupil school expenditures can be further divided into two categories: per-pupil personnel expenditures and operating expenses, separately for primary and middle schools. The largest component of the personnel expenditures is the salaries of teachers and staff, which are inelastic by nature, while operating expenses are more discretionary.

School enrollments. We construct several educational outcomes using China's population mini-census in $2005 .{ }^{14}$ These outcomes include primary and middle school enrollment rates.

\footnotetext{
expenditure data are only available within this time range.

13 City districts generally have better economic conditions than counties to fulfill the compulsory education targets, so our focus on counties home to over $98.6 \%$ of China's population in 1993 but facing heavier fiscal pressure from compulsory education can be rationalized.

${ }_{14}$ Our analysis data set is a $20 \%$ random sample of the original 2005 population mini-census (covering $0.2 \%$ of China's total population), which is provided by China's National Bureau of Statistics. Note that an advantage
} 
Since the population census contains no information about the starting and ending years of schooling for each respondent, we define the middle school enrollment rate as the proportion of 13-15 years old children for each year in a given county who had ever enrolled in middle school. Similarly, the primary school enrollment rate is constructed using 7 to 12 -year-old children. Of course, a relatively small proportion of school-age children enrolled in but finally dropped out of school. The enrollment rate measurements we constructed here, therefore, represent conservative measures of compulsory school attendance.

Budgetary and economic outcomes. To investigate the effects of the inspection on local budgetary arrangements and economic performance, we collect a full battery of local budgetary outcomes, including budgetary revenue, budgetary expenditure, administrative expenditure, and agricultural expenditure, from various years of County Fiscal Statistical Yearbook, and GDP from several provincial-, prefectural- and county-level statistical yearbooks and chronicles.

County party secretaries' tenure. To link local leaders' political incentives to county governments' window dressing behavior on educational inputs, we manually collect countylevel party secretaries' tenure information from the Organizational History of the Chinese Communist Party of several provinces and hundreds of provincial-, prefectural-, and countylevel chronicles. ${ }^{15}$ Note that the turnovers of county party secretaries could occur at any time of a year. We assign a year to a given county party secretary if his or her tenure covered over six months in the year. ${ }^{16}$

All of the county-level data were adjusted to China's county-level administrative boundaries in 2005 to accord with the 2005 population mini-census data. All time-varying outcomes are adjusted to 1995 constant price using province-level CPI. ${ }^{17}$ Table 1 presents the descriptive statistics for the main variables used in this paper, where Panels A and B are respectively for time-varying outcomes and time-invariant county attributes.

[Table 1 About Here]

\footnotetext{
of the population census is that it is immune to potential data manipulation by local governments.

15 Ideally, we can have access to detailed resume information of county party secretaries to delve deeper into individual-level heterogeneity. However, such data is not readily available.

${ }_{16}$ Our findings are robust to alternative ways to assign a county leader to the specific turnover year. The results are available from the authors upon request.

17 The province-level CPI data comes from various years of China's Statistical Yearbook.
} 


\subsection{Empirical Strategy}

We implement a staggered difference-in-differences (DID) strategy in an event study specification as follows:

$$
y_{c, p, t}=a+\sum_{k=-5}^{5} \tau_{k} \text { Inspect }_{c, t, k} \times \text { Treat }_{c}+\mu_{c}+\eta_{p, t}+\beta \text { Treat }_{c} \times t+\left(X_{c} \times \gamma_{t}\right) \boldsymbol{\theta}+\varepsilon_{c, p, t},
$$

where the subscripts $c, p$, and $t$ represent county, province, and year, respectively. $y_{c, p, t}$ is the outcome variable of our interest in county $c$ in province $p$ in year $t . \mu_{c}$ denotes county fixed effects, and $\eta_{p, t}$ denotes the province-by-year fixed effects so that we focus on intra-provincial comparison. Inspect $t_{c, t, k}$ is a set of dummy variables indicating the different timings relative to the pre-specified inspection year of county $c$; for example, Inspect $t_{c, t, k=-4}=1$ if year $t$ is 4 years before the pre-specified inspection year for county $c$; Inspect $t_{c, t, k=1}=1$ if year $t$ is 1 year after county $c$ 's inspection year; Inspect $t_{c, t, 0}=1$ if year $t$ is the exact year that county $c$ received the inspection, and it is omitted as the reference year, thus the parameters of interest $\tau_{k}$ we estimate can be interpreted as the effects relative to the inspection year. Also, Inspect $t_{c, t, k=-5}=1$ (respectively, $\operatorname{Inspect}_{c, t, k=5}=1$ ) if yeart $t$ is 5 or more years before (respectively, after) the prespecified inspection year for county $c$. Treat $c$ is a dummy that takes value 1 if county $c$ received the inspection before the year 2001 and 0 otherwise. Finally, $X_{c}$ is a list of county characteristics we detail below.

As is standard in difference-in-differences estimations, interpreting our estimated coefficient as a causal effect relies on the parallel pre-trend assumption to be meet between treatment and control counties. However, as we have described, the inspection sequence is not random, which puts us at risk of violating this assumption. To understand the determinants of the scheduled inspection sequence, we estimate an ordered Probit model using a full battery of pre-determined county characteristics (denoted $X_{c}$ ). The results are presented in Appendix Table A1. Generally, counties with poor economic endowments (counties with higher average elevation and slope, National Poor Counties, or minority counties) became CCECs later. ${ }^{18} \mathrm{We}$ also find that the inspection year tends to be later for counties with a smaller proportion of residents with middle school literacy in 1990. These findings are consistent with the fact

\footnotetext{
18 In 1993, 592 counties were officially approved as National Poor Counties (NPCs) in China.
} 
described in Section 2 that the poor counties with difficulties in fulfilling the targets were inspected later.

Motivated by these findings, we control for the interactions of a full set of year dummies with these pre-determined time-invariant county attributes $\left(X_{C} \times \gamma_{t}\right)$ to capture the differences in the outcomes $y_{c, p, t}$ that may arise from the differences in these county attributes. As previously explained, our sample only covers the period of 1993-2001. To further eliminate concerns on non-parallel trends of outcomes arising from counties not receiving treatment within our sample coverage, we control for the linear time trends for the treatment group counties (i.e., counties passing the inspection before 2001), which is denoted by Treat $_{c} \times t$. Standard errors throughout all panel regressions in this paper are clustered at the county level to address potential serial correlation and heteroscedasticity of the error terms.

Apart from the dynamic patterns depicted in the event study specification, we are also concerned about the average treatment effects of being approved as a CCEC, which can be identified as $\tau$ in the following DID specification in Equation (2):

$$
y_{c, p, t}=\alpha+\tau C C E C_{c, p, t} \times \text { Treat }_{c}+\mu_{c}+\eta_{p, t}+\beta \text { Treat }_{c} \times t+\left(X_{c} \times \gamma_{t}\right) \boldsymbol{\theta}+\varepsilon_{c, p, t},
$$

where $C C E C_{c, p, t}$ equals one if county $c$ in province $p$ received CCEC certification before year $t$. Other variables are defined in the same way as those in Equation (1).

\section{The Effects of Inspections on Educational Inputs}

In this section we examine our main hypothesis that the CCEC inspection will incentivize county governments to increase educational inputs before the inspection, but decrease education inputs significantly in the post-inspection period.

\subsection{Effects on Educational Inputs}

We start by examining the impacts of the program on educational inputs. Figure 3 presents the event study results with the specification in Equation (1). As shown in Panel A, total educational expenditure gradually increased in pre-inspection years and reached its peak in the inspection year or the year preceding the scheduled inspection. However, immediately after passing the inspection, the total educational expenditure experienced a significant decrease of about $8 \%$. This sizable drop in educational expenditures lasted even five years after the 
inspection. This pattern documents clear evidence of window-dressing behavior in fulfilling the compulsory education targets: to meet the target, county governments boosted educational expenditures to increase the school enrollments, but once the inspection was finished and the CCEC status was awarded, the education-promotion efforts slacked off immediately and significant cuts in education expenditures occurred in the subsequent years.

[Figure 3 About Here]

Panels B and C of Figure 3 show the event study estimates of the fiscal and non-fiscal education expenditures before and after the inspection. Both fiscal and non-fiscal expenditures display a similar trend-break decrease after passing the inspection, but there is an interesting difference in the pre-trend before the inspection. The fiscal educational expenditures had a virtually flat pre-trend, while non-fiscal educational expenditures experienced a more salient increase before the inspection. The post-inspection decrease of fiscal educational expenditures is approximately $4-5 \%$ annually in the first three years, and that for the non-fiscal educational expenditures experienced a much more striking decrease of about $17 \%$ annually, which is consistent with our discussion in Section 2. When local leaders were confronted with the challenge of meeting the educational targets, they had limited discretion to increase fiscal expenditures. After the 1994 tax-sharing reform, the county governments retained a relatively small fraction of tax revenues (Wong, 2000) and the fiscal educational expenditures were mainly financed by intergovernmental transfer payments from the upper-level governments. As a result, local governments had to turn to non-fiscal funding sources to meet with the challenges of financing compulsory education.

Our interpretation of Panels B and C of Figure 3 can be further supported by the evidence uncovered in Panel D. As described in Section 2, local governments had discretionary power in determining the rural educational surcharge rate, which became the lever through which the county leaders shifted the financial burden from fiscal to non-fiscal categories to achieve the compulsory educational targets; once passing the inspection, however, they significantly lowered the rural educational surcharge rate for at least five years. In this sense, Panel D provides evidence on the withdrawal of surcharges financing compulsory education, which underlies the slack-off of non-fiscal education expenditures after the inspection, as shown in 
Panel C.

[Table 2 About Here]

To give a sense of the average treatment effect of inspection on educational inputs, Table 2 presents the DID results using the specification of Equation (2). In Column 1, we show that the total educational expenditures saw a 9.1\% reduction following the CCEC certification. Columns 2-3 investigate, respectively, the impacts on the fiscal and non-fiscal components of total educational expenditure. The point estimates are respectively $4.2 \%$ for fiscal educational expenditure in Column 2 and 16.9\% for non-fiscal educational expenditures in Column 3, which are consistent with the dynamic effects illustrated in Figure 3. Column 4 suggests that passing the CCEC inspection is associated with a 0.065 percentage point reduction in the rural educational surcharge rate (the mean rural educational surcharge rate is 0.73 percentage point).

So far, the different pieces of evidence presented in Figure 3 and Table 2 paint a consistent picture that there were some efforts for the county governments to increase education expenditures before the inspection, but these efforts were reversed significantly after the inspection. We consider the salient drop of educational inputs immediately after the inspection as the primary evidence of the window-dressing behavior. Our subsequent analysis will document more evidence to lend support to the window dressing hypothesis.

\subsection{Robustness checks}

We conduct several robustness checks to address potential concerns about our DID results. The results are presented in Table 3. In Panel A, we exclude all counties not required to receive inspection before 2001 (i.e., counties marked in a darker color in Appendix Figure A1) and reruns our baseline DID specification of Equation (2). ${ }^{19}$ The findings are qualitatively and quantitatively similar to our baseline results, suggesting that our results are not driven by the differences between the control and treatment counties. In Panel B, we replace the provinceyear fixed effects by more detailed prefecture-by-year fixed effects, in which all prefectureyear-invariant confounding factors are eliminated. The estimates are robust. In Panel C, we allow each county to have its own linear and quadratic time trends to address concerns on non-

\footnotetext{
19 When excluding counties that were not required to receive inspection before 2001 (i.e., Treat $_{c}=0$ ), Equation (2) is reduced to a staggered simple difference estimation.
} 
parallel trends. Again the results remain highly robust. Finally, to address the concern that our findings might be driven by local political cycles, in Panel D we further control for county party secretary fixed effects. Both the economic magnitude and the statistical significance of each estimated coefficients change only slightly.

\section{[Table 3 About Here]}

\subsection{Effects on regional development and local budgetary arrangements}

This part examines the impact of the compulsory educational target policy on regional development and local budgetary arrangements. The results are presented in Table 4. Columns 1-2 show that the program had no impacts on county GDP and budgetary revenue, thus the abrupt reduction in educational expenditures after the inspection was not caused by negative local economic shocks. Column 3 also reveals no significant impact on the county's overall budgetary expenditures, which rules out a competing hypothesis that the results we reported in Table 2 were driven by reductions in intergovernmental transfers. In Column 4, we examine the program's impact on administrative expenditures and agricultural expenditures and find that the CCEC certification had an insignificant effect on administrative expenditures. This result serves as a placebo test as the CCEC inspection had nothing to do with other governmental functions other than compulsory education promotion. Column 5 shows that the budgetary agricultural expenditures increased by about $2.3 \%$ in post-inspection years, which is suggestive of a reallocation of fiscal resources from the educational sector to the agricultural production sector after the window dressing behavior to pass the inspection.

[Table 4 About Here]

\subsection{Mechanism}

One may argue that a sharp drop in educational expenditures after the inspection could be a natural result of educational investment dynamics, and has nothing to do with windowdressing incentives. For example, to achieve the educational target, local governments might need to construct school facilities to accommodate more students. When all the school facilities were built up and the school enrollment target was fulfilled, we would naturally see a drop in educational investment. As mentioned in Section 3.1, we excluded school facility construction 
expenditures in the measure of educational inputs analyzed in this paper, and the school facility constructions were funded through special-purpose appropriations in the Chinese fiscal system. In other words, the education expenditures used in our analysis consist of primary expenditures on the wage bills of teachers and staff (personnel expenditures), and school management and operations (operating expenses). These expenditures should vary proportionally with the size of school enrollment over the county. If the county government tried its utmost to maintain the targeted level of student enrollment after the inspection, we should not see a sharp decline immediately after the inspection.

To further address this issue, we explore the effect of the CCEC inspection on per-pupil total educational expenditures, and categorical expenditure for both primary and middle school outcomes in Table 5. Consistent with our key findings on overall educational expenditure in Table 2, Columns 1 and 4 in Table 5 suggest that passing the CCEC inspection caused per-pupil expenditures on primary and middle schools to drop by $1.8 \%$ and $6.3 \%$, respectively. As alluded to in Section 2, achieving the target for compulsory middle school enrollment was much harder than achieving the primary school enrollment, which was already over $97 \%$ in the early 1990s. Thus, we observe a much larger decrease in per-pupil expenditures of middle schools than that of primary schools.

\section{[Table 5 About Here]}

In what follows, we will examine the inspection's heterogeneous effect on personnel expenditures and operating expenses of both primary and middle schools. The personnel expenditures constitute a much larger share of educational expenditures, about $91.5 \%$ on average for primary schools and $88.5 \%$ on average for middle schools during our sample period, and they are mostly downward rigid. In contrast, operating expenses are subject to considerable adjustment. In China, operating expenses on education include (i) expenditures on school management, teacher training, experiments and practice, (ii) recreational and sports activities, (iii) electricity, heat, and water supply, (iv) equipment and books acquisition, and (v) repairs and maintenance for facilities.

The different elasticities of personnel and operating expenditures in response to fiscal pressures imposed by the inspection can shed some light on the mechanism of window dressing. 
The estimates in Columns 3 and 6 of Table 5 show that, after the inspection, the per-pupil operating expenses shrunk by approximately $21 \%$ for primary schools and $39 \%$ for middle schools on average. However, per-pupil personnel expenditures, both for primary and middle schools, exhibited no significant changes after the inspection, as shown by the point estimates in Columns 2 and 5, which are indistinguishable from zero. The evidence documented above suggests that the county governments mainly reduced the educational expenses by cutting down non-rigid operating expenses when there was no longer a need for window dressing after passing the inspection. Since operating expenses are recurrent expenses, this finding also helps to alleviate the concern that the main results in Table 2 were a result of a natural contraction of one-off expenditures.

\section{Evidence on the Effects of Political Incentives}

The underlying driving force for the window dressing behavior documented above is the political incentive of county leaders in response to the superiors' inspection. As discussed in Section 2.1, the Chinese central government explicitly announced that county party secretaries should take primary responsibility for passing the CCEC inspection according to the prespecified timeline. In reality, county party secretaries often turn over every few years. Even though a full term lasts five years, according to our calculation, the average tenure of China's county party secretaries in office in 1993-2000 was only about 3.5 years. We first show that the pre-specified inspection time for a county was independent of the tenure of the specific county party secretary; thus, everything else equal, a county party secretary who took office close to the pre-specified CCEC inspection time would have a higher incentive to maintain a high level of educational inputs than a counterpart who was to leave the county leadership position soon (for having served in the position for longer than the normal tenure of 3.5 years). The former should face a much larger probability of receiving the inspection during his (or her) own term than the latter who would expect to be leaving before the inspection.

Before exploring the different responses to the inspection by county party secretaries with different inauguration time, let us first check whether the timing of county party secretary turnovers is indeed uncorrelated with the timing of inspections. Using our manually collected 
tenure information of county party secretaries, we run a regression as specified in Equation (1) but replace the dependent variable with a dummy indicating whether there is a turnover of county party secretary in a given year. Figure A2 in the appendix presents the results, which show that the timing of a county receiving inspection is orthogonal to the turnover of county party secretary since all of the estimated coefficients of the period dummies are statistically indistinguishable from zero.

This exercise also helps to address another potential concern that the fluctuations of educational inputs we observed in Table 2 and Figure 3 may coincide with local political cycles. There has been an intensive literature emphasizing the critical role of Chinese local government officials in managing local economic development and allocating local resources ( $\mathrm{Li}$ and Zhou, 2005; Xu, 2011; Xiong, 2018). Guo (2009) provides evidence on the effects of local political cycles in China, namely the turnover of county party secretaries, on county fiscal expenditures. Since Figure A2 shows that the timing of the political turnover of county party secretaries is uncorrelated with the timing of inspections, we can reasonably reject the alternative interpretation that the significant reduction of education expenditures after the inspection was driven by local political cycles.

In what follows, we investigate how the effects of the CCEC inspection are correlated with the mismatch of the tenures of county party secretaries with the pre-specified inspection time which we use to proxy for their window-dressing incentives. The fact that the inauguration year of a county party secretary's tenure is independent of the compulsory education policy offers us valuable quasi-exogenous variations to unveil the political incentive of local leaders. Motivated by this hypothesis, we implement the following event study regression equation:

$$
y_{c, p, t}=\alpha+\sum_{k=-5}^{1} \tau_{k} \operatorname{Gap}_{i, c, t, k} \times \text { Treat }_{c}+\mu_{c}+\eta_{p, t}+\beta \text { Treat }_{c} \times t+\left(X_{c} \times \gamma_{t}\right) \boldsymbol{\theta}+\varepsilon_{c, p, t}
$$

where $\operatorname{Gap}_{i, c, t, k}$ is a dummy denoting that the observation in year $t$ of county $c$ belongs to party secretary $i$ who took office $k$ years from the pre-specified inspection year. ${ }^{20}$ For example, $\operatorname{Gap}_{i, c, t, k \geq 1}=1$ if year $t$ of county $c$ was under the rule of party secretary $i$ who took office one or more years after the pre-specified inspection year for county $c$, which is omitted as the reference group. Other variables are defined similarly to those for Equation (1). This strategy

\footnotetext{
${ }^{20}$ Figure A3 plots the histogram of the distance between county party secretaries' inauguration year and the inspection year in our regression sample.
} 
compares the average outcomes of a county under the leadership of the party secretaries taking office in a time very close to the inspection year with those of a county whose party secretary took office after the pre-specified inspection.

[Figure 4 About Here]

Figure 4 plots the event study results on the effect of the inauguration time on the same set of educational inputs as in Table 2. Panel A shows that as the inauguration year is closer to the inspection year, other things being equal, the increase in county educational expenditures becomes significantly larger. When the party secretary took office only one year away from the inspection year, the educational budget increased by about $4 \%$ from the benchmark level of the control group. We interpret this pattern as consistent with our window dressing hypothesis. When the inauguration time approached the pre-specified inspection time, the pressure of meeting the compulsory education target was more likely to be binding, and thereby the party secretary should respond more aggressively to avoid the severe career consequences of "oneitem-veto." Panel A in Figure 4 exactly depicts such an empirical fact. We find that the major effect of the Gap comes from the non-fiscal educational expenditures, which are more discretionary and flexible. This finding is similar to what we found in Panels B and C of Figure 3. Panel D in Figure 4 provides further evidence to support the window dressing hypothesis: when the Gap was smaller, the rural education surcharge rate became higher.

The county party secretaries taking office exactly in the inspection year deserves special consideration. In all four panels in Figure 4, we find that if the inauguration year coincided with the inspection year, both education expenditures (including their subcategories) and rural educational surcharge rate went down compared to those whose term started one year before the inspection. This follows from the convention that the departing, rather than the incoming county leader, should be responsible for whether or not the county passed the inspection.

Taken together, the patterns shown in this subsection indicate that county party secretaries who were more likely to bear potential political punishment if not meeting the target responded more aggressively to the approaching inspections. These pieces of evidence lend support to the underlying linkage between the window dressing phenomenon and the political incentives of the local leaders. 


\section{The Impact of Inspections on School Enrollment}

So far, we documented the evidence of window dressing before the inspection, followed by significant reductions of county-level educational expenses after passing the CCEC inspections, and of its linkage to county leaders' political incentives. In this section, we explore the effects of CCEC inspection on children's educational attainment, the key target of the compulsory education campaign in China, and examine how these effects are distributed across different groups of students (e.g., urban vs. rural, male vs. female).

China's official statistical yearbooks contain data on the size of in-school students for both primary and secondary schools. However, we do not use these data in our analysis for two reasons. First, the official school statistics may be subject to data manipulation, as widely documented in the literature (for example, Fisman and Wang, 2017; Xiong, 2018). Second, the official data only reports the aggregated statistics for secondary schools. In China, secondary schools consist of middle schools and high schools. China's Compulsory Schooling Law concerns the middle school enrollment only, without making any requirement on high school enrollment. Although middle school students generally accounted for over $80 \%$ of the secondary school students in the 1990s, ${ }^{21}$ the mixture of middle schools and high schools in the official school statistics could confound our analysis. We instead use China's 2005 population mini-census to back out the county-level enrollment rates of students at primary school age (7-12 years old) and middle school age (13-15 years old). Another distinct advantage of using population census data is that we can calculate the average enrollments for several groups to examine the distributional effects of local governments' window dressing behaviors.

\section{[Table 6 About Here]}

Table 6 reports the DID regression results using the regression specification of Equation (2), with dependent variables being the primary and middle school enrollments. Given that primary school enrollment rate had reached a fairly high level (i.e., about 98\%) at that time, it is reasonable to observe in Column 1 that primary school enrollment rate remained virtually unchanged after the inspection. In stark contrast, Column 2 reports a significant one percentage

21 According to China's Educational Statistical Yearbook in 2002, high school students accounted for about $17.9 \%$ of the secondary school students in 2001 , the end year of our sample period. 
point decline of middle school enrollment rate after the inspection. Panel A in Figure 5 shows a dynamic pattern of middle school enrollment before and after the inspection, using the eventstudy specification in Equation (1). We can observe an increase of middle school enrollment, although statistically insignificant, before the inspection, but a significant and sustained drop after the inspection. This pattern is consistent with the fact illustrated in Figure 3 on educational inputs.

\section{[Figure 5 About Here]}

Although we do not know exactly the primary and middle school enrollment rates for those counties at the time of inspection and evaluation, we can reasonably assume that most inspected counties would hit the minimal targets mandated by the Compulsory Schooling Promotion Program, due to the popular unwillingness among county leaders to invest in local elementary education. Under this assumption, when we observe an average decline of $1 \%$ in enrollments for middle schools, it is reasonable to argue that after the inspection, the once barely-achieved target level of school enrollment would likely drop to a level below the target. This further bolsters our interpretation of the documented behavior of the local government as window dressing.

Next, we further examine the heterogeneous effect of inspections on middle school enrollment. We are concerned about how the decline of middle school enrollment was distributed across urban-rural divisions and genders. Columns 2-4 of Table 6 demonstrate that the adverse effects of the window addressing behavior are unevenly distributed. Particularly, rural girls suffered more severely (with a highly significant point estimate of -1.19). This is understandable: when the county governments attempted to fulfill the compulsory education target (especially for middle school enrollment), expanding rural schools to accommodate a large pool of rural children of school age was the largest fiscal challenge. Therefore, once the target was accomplished, and knowing that there was no inspection anymore, the education inputs in rural schools dropped immediately. The urban education would suffer much less since it had better endowments and facilities than rural areas. Similarly, when access to schools became harder, girls were more likely to be deprived of educational opportunities than boys, especially in rural areas. 
There exists a possibility that our findings are driven by endogenous migration of children from non-CCECs (generally poorer counties) to the CCECs. To address this concern, we exclude immigrants from the sample, namely those individuals whose birthplaces were different from their current residences and repeat the regressions of Table 6 . All of the estimates, as presented in Table A3, are quantitatively similar to the corresponding results in Table 6 .

Finally, to further rule out the possibility that the potential confounding factors correlated with the inspection events and the middle school enrollment rate drive our findings, we use a widely used machine learning method, the random forest model, to construct a counterfactual for middle school enrollment rate in the absence of the program. Specifically, we use four input variables, the logarithm of per capita rural income, average elevation, average slope, and the minority county dummy, and the panel data in 1990-1992, to train our random forest model. ${ }^{22}$ From Figure B1 in the appendix, we can see that the predictions of the random forest model fit the original data quite well (the estimated slope is 1.019 , with an R-squared of 0.70 ). Next, we use the random forest model to predict outcomes by plugging in the data of the covariates in 1993-2001. Figure B2 in the appendix compares the evolving trend of the predicted middle school enrollment rate and the middle school enrollment rate constructed from the 2005 population mini-census in 1990-2001. There is an evident trend break from 1993 on, revealing that the CCEC inspection might have a positive impact on middle school enrollments by incentivizing local governments in pre-inspection years.

We use the predicted middle school enrollment rate as an outcome to conduct a placebo test, using the specification in Equation (1). The results are illustrated in Panel B of Figure 5. We cannot observe any trend break after the inspection. This is in stark contrast with Panel A of Figure 5, which shows the event study results using the constructed middle school enrollment rates from the 2005 population mini-census as the dependent variable. The dynamic patterns in Panels A and B support our interpretation that the discontinuous change of middle school enrollment observed in the data is not due to any discrete changes in county-level attributes and rural economic development.

${ }^{22}$ We set the number of random forest trees to generate the model at 100 , according to the well-accepted practice in the literature. We also set the minimum number of observations in each tree leaf node at one, and do not restrict the maximum depth of the random forest tree (the length of the longest path from the root to the leaf node). Our results are robust to using alternative covariates and specifications to construct the random forest model. 
To summarize, the window dressing behavior trigged by the CCEC inspections was detrimental to the middle school attainment for the affected cohorts. Given China's large population, a one-percentage-point reduction in middle school enrollment implies that 346 thousand school-age children were out of school every year. Furthermore, the deterioration in school enrollment generated distributional consequences since rural girls bore the blunt of the decline in middle school enrollment.

\section{Conclusion}

Window dressing is a common strategic reaction to incentive schemes observed in various types of organizations. While the existing literature has focused on the window dressing behavior in the private sector, we provide evidence of window dressing phenomenon in the public sector by studying the strategic responses of Chinese local officials to the compulsory education promotion program launched by the central government in the 1990s. According to this program, the Chinese counties should receive inspections on whether the compulsory educational targets were achieved on pre-scheduled time by provincial governments; and failing to pass the inspection would have severe negative career consequences for the county leaders. We find that county-level educational expenditures saw a sustained increase before the inspection, but a sharp drop immediately after the inspection. Local officials who were more likely to be inspected within their tenures window-dressed more aggressively. As a result, middle school enrollment rates declined significantly after the inspection, and rural girls bore the blunt of the decline in school enrollment.

We believe that the window dressing incentives we uncover for government officials are not specific to China, and apply to any authoritarian system with top-down political incentives. More broadly, this paper is an application of, and provide empirical evidence for, the classic incentive theory that emphasizes the potential pitfalls of high-powered incentives in the public sector (Finan et al., 2017).

\section{References}

Acemoglu, D., Fergusson, L., Robinson, J. A., Romero, D., \& Vargas, J. F. (2018). The Perils of high- 
powered incentives: Evidence from Colombia's false positives. American Economic Journal: Economic Policy.

Agarwal, V., Gay, G. D. \& Ling, L. (2014). Window dressing in mutual funds. The Review of Financial Studies, 27(11), 3133-3170.

Alatas, V., Banerjee, A., Hanna, R., Olken, B. A., Purnamasari, R., \& Wai-Poi, M. (2019, May). Does elite capture matter? Local elites and targeted welfare programs in Indonesia. In AEA Papers and Proceedings (Vol. 109, pp. 334-39).

Allen, L. \& Saunders, A. (1992). Bank window dressing: Theory and evidence. Journal of Banking \& Finance, 16(3), 585-623.

Banerjee, A. V., Duflo, E., \& Glennerster, R. (2008). Putting a band-aid on a corpse: Incentives for nurses in the Indian public health care system. Journal of the European Economic Association, 6 (2-3): 487-500.

Bardhan, P. K. \& Mookherjee, D. (2000). Capture and governance at local and national levels. American Economic Review, 90(2), 135-139.

Bardhan, P. \& Mookherjee, D. (2005). Decentralizing antipoverty program delivery in developing countries. Journal of Public Economics, 89(4), 675-704.

Bardhan, P. \& Mookherjee, D. (2006). Decentralisation and accountability in infrastructure delivery in developing countries. Economic Journal, 116(508), 101-127.

Bischoff, I. \& Blaeschke, F. (2016). Performance budgeting: Incentives and social waste from window dressing. Journal of Public Administration Research and Theory, 26(2), 344-358.

Cao, Y., Fisman, R.J., Lin, H., and Wang, Y. (2018). Target setting and allocative inefficiency in lending: Evidence from two Chinese banks. NBER Working Paper, (w24961).

Chen, Y. J., Li, P., \& Lu, Y. (2018). Career concerns and multitasking local bureaucrats: Evidence of a target-based performance evaluation system in China. Journal of Development Economics, 133: 84101.

Courty, P., \& Marschke, G. (1997). Measuring government performance: Lessons from a federal jobtraining program. American Economic Review, 87(2), 383-388.

Courty, P., \& Marschke, G. (2004). An empirical investigation of gaming responses to explicit performance incentives. Journal of Labor Economics, 22(1), 23-56. 
Ferraz, C. \& Finan, F. (2011). Electoral accountability and corruption: Evidence from the audits of local governments. American Economic Review, 101(4), 1274-1311.

Finan, F., Olken, B. A., \& Pande, R. (2017). The Personnel economics of the developing state. Handbook of Economic Field Experiments, 2: 467-514.

Fisman, R., \& Wang, Y. (2015). The Mortality cost of political connections. The Review of Economic Studies, 82(4), 1346-1382.

Fisman, R., \& Wang, Y. (2017). The Distortionary effects of incentives in government: Evidence from China's 'Death Ceiling' program. American Economic Journal: Applied Economics, 9(2), 202-18.

Garicano, L., \& Rayo, L. (2016). Why organizations fail: models and cases. Journal of Economic Literature, 54(1), 137-92.

Greenstone, M., He, G., Jia, R., \& Liu, T. (2020). Can technology solve the principal-agent problem? Evidence from China's War on Air Pollution (No. w27502). National Bureau of Economic Research.

Guo, Gang (2009). China's local political budget cycles. American Journal of Political Science 53(3), $621-632$.

He, G., Wang, S., \& Zhang, B. (2020). Watering down environmental regulation in China. Quarterly Journal of Economics.

Holmstrom, B. \& Milgrom, P. (1991). Multitask principal-agent analyses: Incentive contracts, asset ownership, and job design. Journal of Law, Economics, \& Organization, 7: 24-52.

Jia R, Kudamatsu M, \& Seim D. (2015). Political selection in China: The complementary roles of connections and performance. Journal of the European Economic Association, 13(4), 631-668.

Jia, R. (2017). Pollution for promotion. Working paper.

Lakonishok, J., Shleifer, A., Thaler, R. \& Vishny, R. (1991). Window dressing by pension fund managers, American Economic Review Papers and Proceedings, 81(2), 227-231.

Li, H., and Zhou, L. A. (2005). Political turnover and economic performance: The incentive Role of Personnel Control in China. Journal of Public Economics, 89(9-10), 1743-1762.

Liebman, J. B., \& Mahoney, N. (2017). Do expiring budgets lead to wasteful year-end spending? Evidence from federal procurement. American Economic Review, 107(11), 3510-49.

Lou, J. and Wang, S. (2007). Public Finance in China: Reform and Growth for a Harmonious Society, Washington. D. C.: The World Bank. 
Oyer, P. (1998). Fiscal year ends and nonlinear incentive contracts: The effect on business seasonality. Quarterly Journal of Economics, 113(1), 149-185.

Shi, X., \& Xi, T. (2018). Race to safety: Political competition, neighborhood effects, and coal mine deaths in China. Journal of Development Economics, 131, 79-95.

Smith, T. B. (1991). The comparative analysis of bureaucratic accountability. Asian Journal of Public Administration, 13(1), 93-104.

Wang, Z., Zhang, Q., \& Zhou, L. A. (2019). Career incentives of city leaders and urban spatial expansion in China. Review of Economics and Statistics, 1-45.

Wong, C. (2000). Central-local relations revisited: The 1994 Tax Sharing Reform and public expenditure management in China. Working Paper, World Bank.

Xiong, W. (2018). The Mandarin model of growth (No. w25296). National Bureau of Economic Research.

$\mathrm{Xu}, \mathrm{C}$. (2011). The fundamental institutions of China's reforms and development. Journal of Economic Literature, 49(4): 1076-1151.

Yao, Y., \& Zhang, M. (2015). Subnational leaders and economic growth: Evidence from Chinese cities. Journal of Economic Growth, 20(4): 405-436. 


\section{Figures and Tables:}

Figure 1: Histogram of Inspection Time

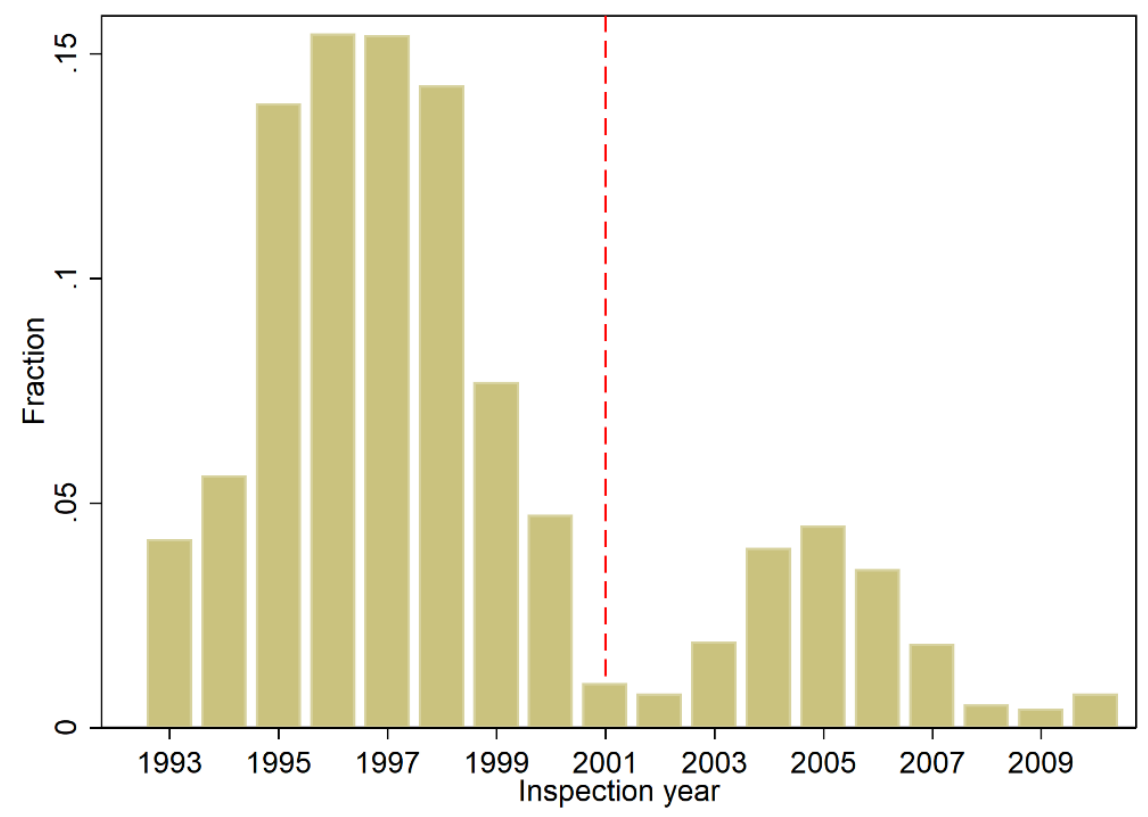

Notes: This figure plots the distribution of inspection years in our analytical sample. Our analyses focus on the period 1993-2001 as detailed county-level outcomes regarding educational input we used in this paper are not available from 2002. The 1691 counties passing the CCEC inspection before 2002 covered about $89.1 \%$ of China's population in 2001 in the full sample.

Figure 2: The Distribution of CCEC Inspections over Time

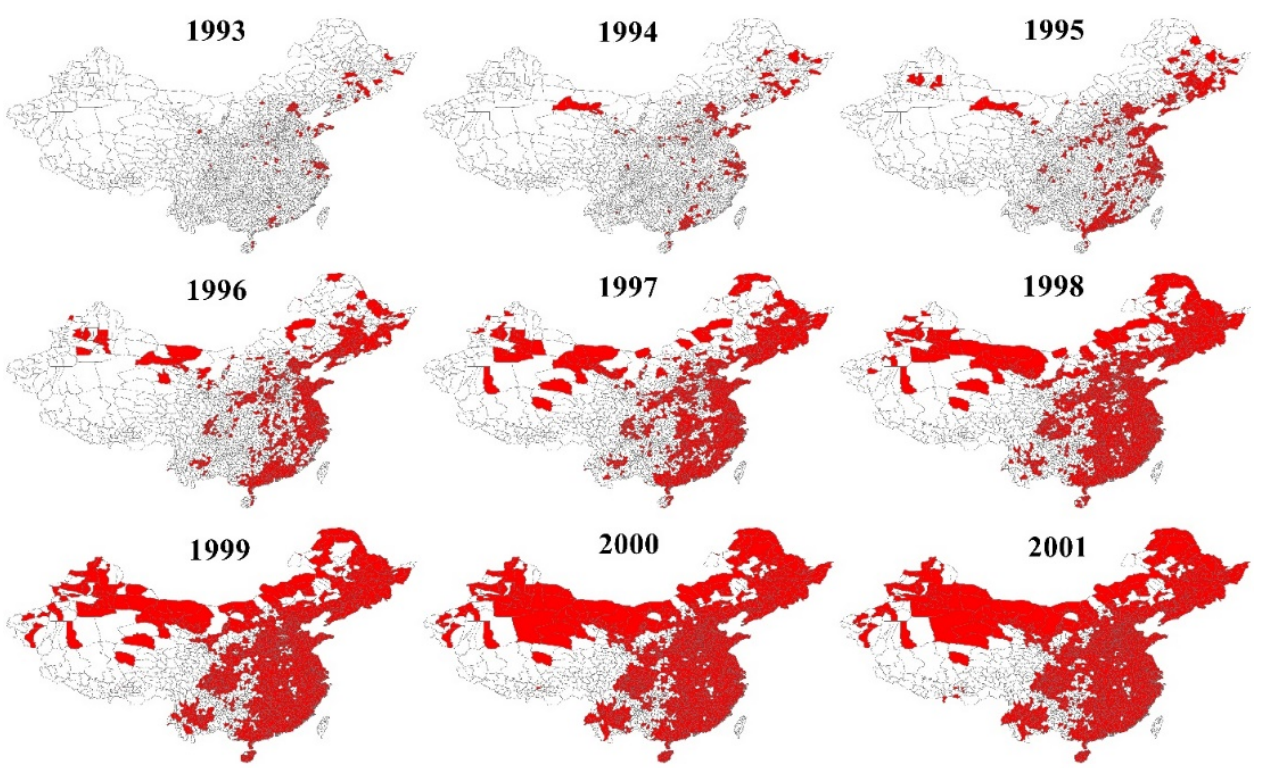

Notes: The counties passing the inspection are marked in red color. 
Figure 3: Educational Inputs Before and After the Inspection
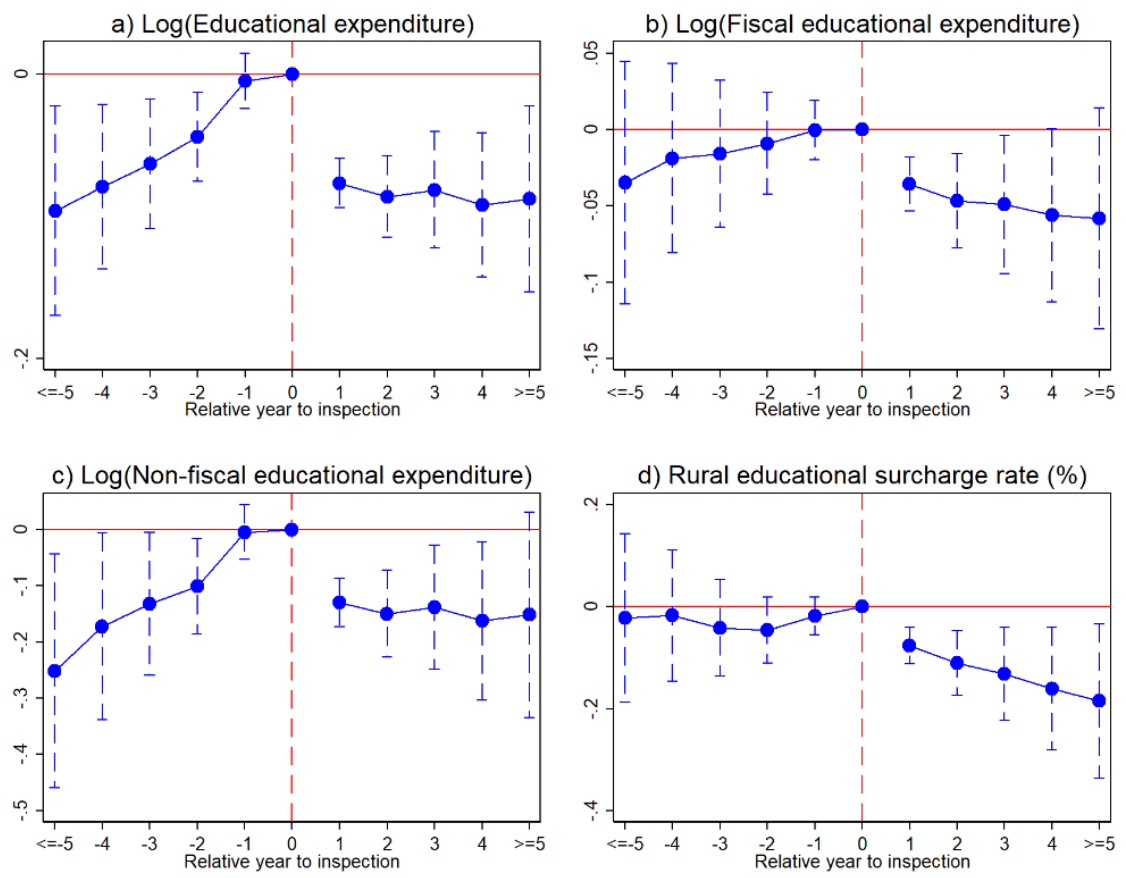

Notes: This figure presents the event study estimates for several county-level education inputs with the specification of Equation (1). The solid circle represents the estimated coefficient for each year relative to the inspection year, along with the $95 \%$ confidence intervals calculated by employing county-level clustered standard errors. 
Figure 4: Effects of the Tenure of County Party Secretaries on Educational Inputs

a) $\log ($ Educational expenditure)

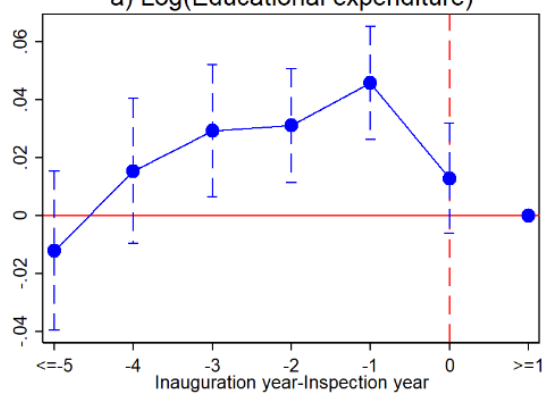

c) Log(Non-fiscal educational expenditure)

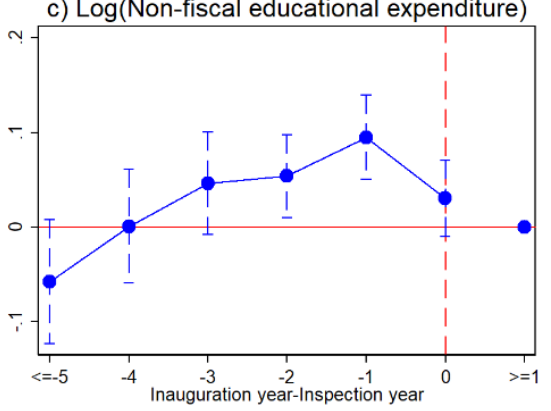

b) $\log ($ Fiscal educational expenditure)

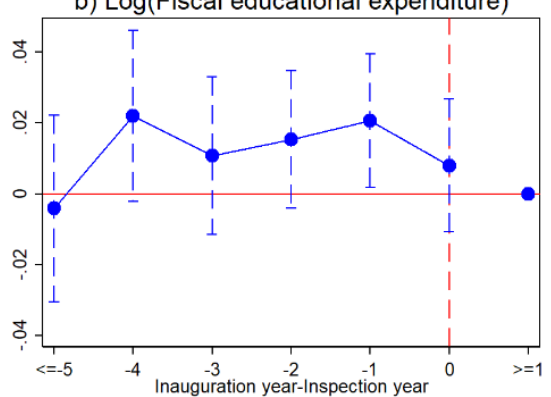

d) Rural educational surcharge rate (\%)

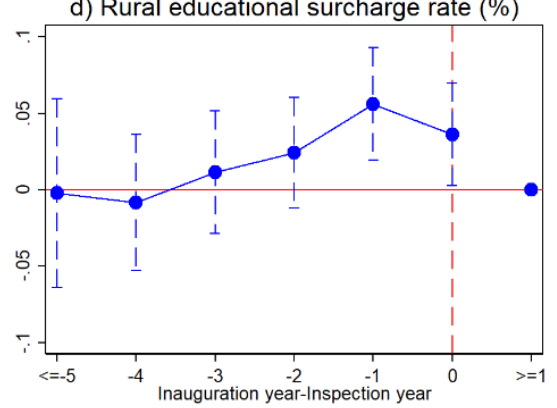

Notes: This figure displays the regression results of Equation (3). County party secretaries who took office after the inspection are omitted as the reference group. The solid circle represents the estimated coefficient for each inauguration year, along with the $95 \%$ confidence intervals calculated by employing county-level clustered standard errors. 
Figure 5: Event Study Results on Middle School Enrollment Rates

Panel A: Actual Data Constructed from Population Census

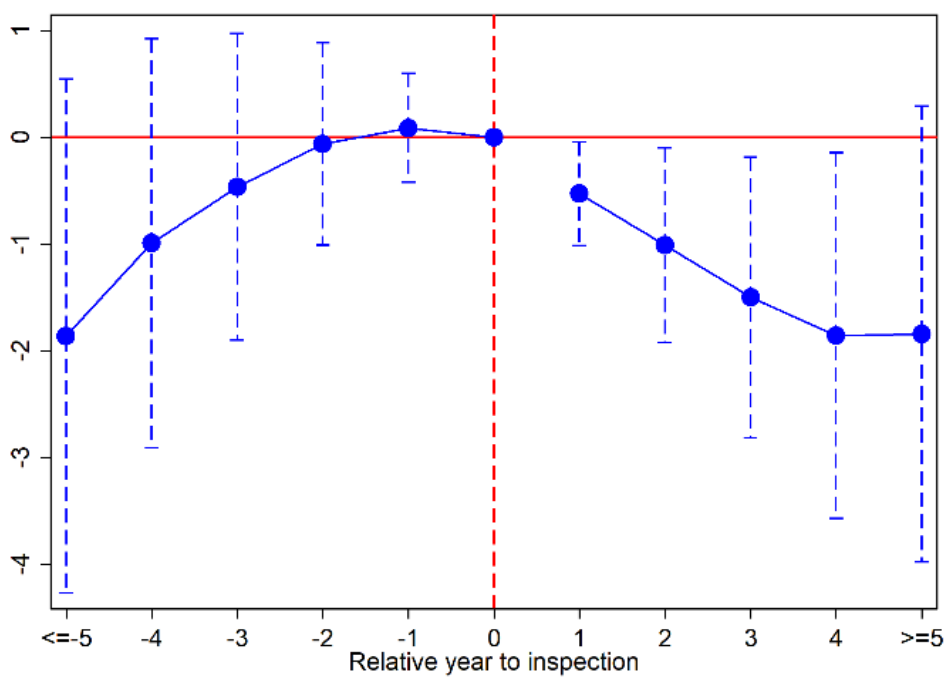

Panel B: Predicted Enrollment Rates Using the Random Forest Model

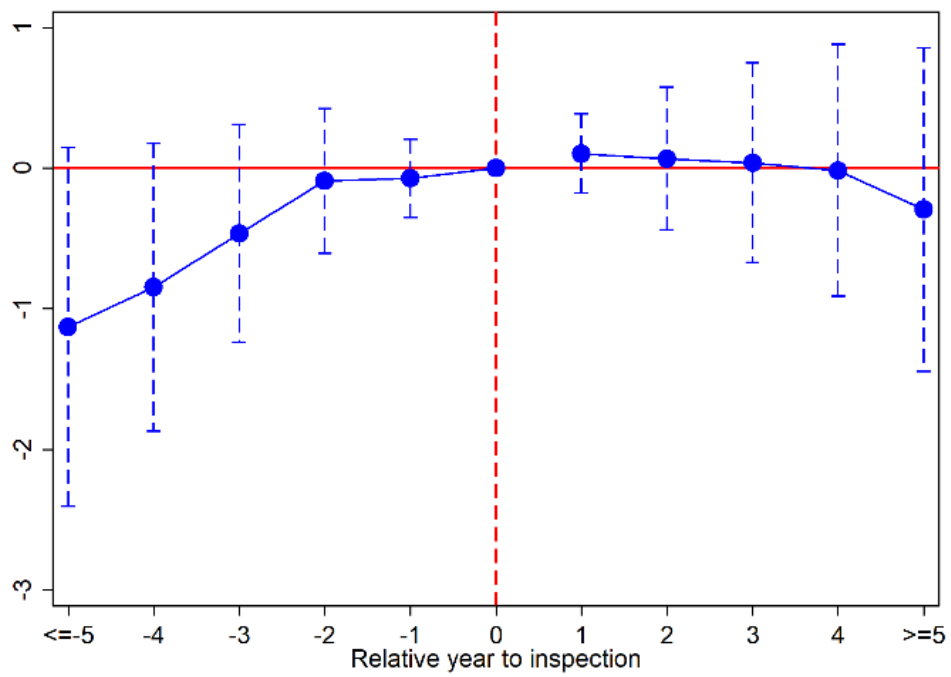

Notes: This figure presents the event study estimates for middle school enrollment rates. Panel A uses the middle school enrollment rates constructed from the 2005 mini-census data. Panel B uses the predicted value of middle school enrollment using the random forest model. See Section 6 for the technical details of our random forest method. The solid circle represents the estimated coefficient for each year relative to the inspection, along with the $95 \%$ confidence intervals calculated by employing county-level clustered standard errors. 
Table 1: Descriptive Statistics

\begin{tabular}{|c|c|c|c|}
\hline Variable & Obs. & Mean & Std. Dev. \\
\hline \multicolumn{4}{|c|}{ Panel A: Time-varying outcomes } \\
\hline Log(Education expenditure) & 15,442 & 8.482 & 0.923 \\
\hline Log(Fiscal education appropriation) & 15,561 & 8.032 & 0.850 \\
\hline Log(Non-fiscal education expenditure) & 15,312 & 7.225 & 1.361 \\
\hline Rural educational surcharge rate (\%) & 14,326 & 0.730 & 0.514 \\
\hline $\log (\mathrm{GDP})$ & 17,653 & 11.61 & 1.132 \\
\hline Log(Budgetary revenue) & 18,166 & 8.376 & 1.077 \\
\hline Log(Budgetary expenditure) & 18,165 & 9.091 & 0.799 \\
\hline $\log ($ Administrative expenditure $)$ & 18,166 & 7.587 & 0.701 \\
\hline $\log ($ Agricultural expenditure $)$ & 18,161 & 6.100 & 0.802 \\
\hline Log(Primary school expenditure, per pupil) & 14,346 & 5.923 & 0.666 \\
\hline Log(Primary school personnel expenditure, per pupil) & 13,544 & 5.854 & 0.649 \\
\hline Log(Primary school operating expenses, per pupil) & 13,544 & 2.657 & 1.582 \\
\hline Log(Middle school expenditure, per pupil) & 14,307 & 6.402 & 0.583 \\
\hline Log(Middle school personnel expenditure, per pupil) & 13,549 & 6.302 & 0.572 \\
\hline Log(Middle school operating expenses, per pupil) & 13,552 & 3.519 & 1.458 \\
\hline Primary school enrollment rate (\%) & 18,504 & 97.96 & 7.693 \\
\hline Middle school enrollment rate (\%) & 18,488 & 82.87 & 19.80 \\
\hline Middle school enrollment rate, urban male (\%) & 13,832 & 97.31 & 11.82 \\
\hline Middle school enrollment rate, urban female (\%) & 14,303 & 97.00 & 11.94 \\
\hline Middle school enrollment rate, rural male (\%) & 18,173 & 83.40 & 21.88 \\
\hline Middle school enrollment rate, rural female (\%) & 18,226 & 78.13 & 24.44 \\
\hline \multicolumn{4}{|c|}{ Panel B: Pre-determined county attributes } \\
\hline Elevation $(\mathrm{m})$ & 2,060 & 778.9 & 897.9 \\
\hline Slope & 2,060 & 2.550 & 2.400 \\
\hline Proportion of citizens with middle school literacy in 1990 (\%) & 2,060 & 32.59 & 10.84 \\
\hline Proportion of citizens with primary school literacy in 1990 (\%) & 2,060 & 75.77 & 12.85 \\
\hline Illiteracy rate in $1990(\%)$ & 2,060 & 26.37 & 13.17 \\
\hline National Poor County & 2,060 & 0.276 & 0.447 \\
\hline Minority county & 2,060 & 0.271 & 0.445 \\
\hline
\end{tabular}


Table 2: Effects of Inspections on Education Inputs

\begin{tabular}{lcccc}
\hline \hline Dep. Var. & $\begin{array}{c}(1) \\
\text { Log(Education } \\
\text { expenditure })\end{array}$ & $\begin{array}{c}\text { Log(Fiscal } \\
\text { education } \\
\text { expenditure) }\end{array}$ & $\begin{array}{c}\text { Log(Non-fiscal } \\
\text { education } \\
\text { expenditure) }\end{array}$ & $\begin{array}{c}\text { (4) } \\
\text { Rural educational } \\
\text { surcharge rate (\%) }\end{array}$ \\
\hline CCEC $\times$ Treat & $-0.091^{* * *}$ & $-0.042^{* * *}$ & $-0.169^{* * *}$ & $-0.065^{* * *}$ \\
Dep. Mean & $(0.007)$ & $(0.007)$ & $(0.016)$ & $(0.013)$ \\
Observations & 8.481 & 8.032 & 7.225 & 0.730 \\
\# of Counties & 15,428 & 15,547 & 15,298 & 14,300 \\
County FE & 2002 & 2002 & 2002 & 1985 \\
Province-Year FE & YES & YES & YES & YES \\
Controls & YES & YES & YES & YES \\
\hline \hline
\end{tabular}

Notes: Robust standard errors are reported in parentheses, clustered at the county level. *** Significant at the 1 percent level, ** Significant at the 5 percent level, * Significant at the 10 percent level. Constant terms and the estimated coefficients of the controls are not reported. 
Table 3: Robustness Checks

(1)

Dep. Var.
(2)

$\log ($ Education expenditure)

$\log ($ Fiscal education
expenditure $)$

(3)

$\log$ (Non-fiscal education expenditure)
(4)

Rural educational surcharge rate

(\%)

\begin{tabular}{lcccc}
\hline Panel A: & \multicolumn{4}{c}{ Excluding counties not required for inspections before 2001 } \\
\hline CCEC $\times$ Treat & $-0.091^{* * *}$ & $-0.041^{* * *}$ & $-0.172^{* * *}$ & $-0.061^{* * *}$ \\
& $(0.007)$ & $(0.007)$ & $(0.016$ & $(0.014)$ \\
Dep. Mean & 8.540 & 8.064 & 7.354 & 0.748 \\
Observations & 13,972 & 14,067 & 13,868 & 13,118 \\
Number of Counties & 1804 & 1804 & 1804 & 1797 \\
\hline Panel B: & \multicolumn{4}{c}{ Controlling for prefecture-year fixed effects } \\
\hline CCEC $\times$ Treat & $-0.088^{* * *}$ & $-0.032^{* * *}$ & $-0.143^{* * *}$ & $-0.072^{* * *}$ \\
& $(0.008)$ & $(0.007)$ & $(0.017)$ & $(0.014)$ \\
Dep. Mean & 8.478 & 8.028 & 7.221 & 0.735 \\
Observations & 15,100 & 15,223 & 14,970 & 13,999 \\
Number of Counties & 1967 & 1967 & 1967 & 1949 \\
\hline Panel C: & \multicolumn{4}{c}{ Allowing for county-specific flexible time trend } \\
\hline CCEC $\times$ Treat & $-0.094^{* * *}$ & $-0.039^{* * *}$ & $-0.162^{* * *}$ & $-0.082^{* * *}$ \\
& $(0.009)$ & $(0.008)$ & $(0.021)$ & $(0.016)$ \\
Dep. Mean & 8.481 & 8.032 & 7.225 & 0.730 \\
Observations & 15,428 & 15,547 & 15,298 & 14,300 \\
Number of Counties & 2002 & 2002 & 2002 & 1985 \\
\hline Panel D: & & Controlling for party secretary fixed effects & \\
\hline CCEC $\times$ Treat & $-0.087^{* * *}$ & $-0.040^{* * *}$ & $-0.150^{* * *}$ & $-0.066^{* * *}$ \\
& $(0.008)$ & $(0.007)$ & $(0.018)$ & $(0.014)$ \\
Dep. Mean & 8.463 & 7.995 & 7.266 & 0.733 \\
Observations & 13,299 & 13,403 & 13,166 & 12,301 \\
Number of Counties & 1947 & 1948 & 1946 & 1927 \\
\hline \hline Nots: $~$ & & & \\
\hline
\end{tabular}

Notes: In Panel A, we exclude counties not required to receive inspection until 2001 (as illustrated in Appendix Figure A1). In Panel B, we exclude counties receiving inspection after 2000 (never-treated counties in our sample). In Panel C, we control for county-specific linear and quadratic time trends. In Panel D, we control for county party secretary fixed effects. Robust standard errors are reported in parentheses, clustered at the county level. *** Significant at the 1 percent level, ** Significant at the 5 percent level, * Significant at the 10 percent level. Constant terms and the estimated coefficients of the controls are not reported. 
Table 4: Regional Economic Development and Budgetary Outcomes

\begin{tabular}{lccccc}
\hline \hline \multirow{2}{*}{ Dep. Var. } & $(1)$ & $(2)$ & $(3)$ & $(4)$ & $(5)$ \\
\cline { 2 - 6 } & Log(GDP) & $\begin{array}{c}\text { Log(Budgetary } \\
\text { revenue) }\end{array}$ & $\begin{array}{c}\text { Log(Budgetary } \\
\text { expenditure) }\end{array}$ & $\begin{array}{c}\text { Log(Administrat } \\
\text { ive expenditure) }\end{array}$ & $\begin{array}{c}\text { Log(Agricultural } \\
\text { expenditure) }\end{array}$ \\
\hline CCEC $\times$ Treat & 0.003 & -0.009 & -0.008 & -0.005 & $0.023^{* * *}$ \\
& $(0.005)$ & $(0.007)$ & $(0.005)$ & $(0.006)$ & $(0.008)$ \\
Dep. Mean & 11.61 & 8.376 & 9.090 & 7.587 & 6.100 \\
Observations & 17,641 & 18,163 & 18,162 & 18,163 & 18,158 \\
\# of Clusters & 2005 & 2042 & 2042 & 2042 & 2041 \\
County FE & YES & YES & YES & YES & YES \\
Province- & YES & YES & YES & YES & YES \\
Year FE & & & & & \\
Controls & YES & YES & YES & YES & YES \\
\hline \hline
\end{tabular}

Notes: Robust standard errors are reported in parentheses, clustered at the county level. *** Significant at the 1 percent level, ${ }^{* *}$ Significant at the 5 percent level, ${ }^{*}$ Significant at the 10 percent level. Constant terms and the estimated coefficients of the controls are not reported.

Table 5: Effects on School Expenditures

\begin{tabular}{|c|c|c|c|c|c|c|}
\hline & (1) & (2) & (3) & (4) & (5) & (6) \\
\hline Dep. Var. & $\begin{array}{l}\text { Log(Primary } \\
\text { school } \\
\text { expenditure, } \\
\text { per pupil) }\end{array}$ & $\begin{array}{l}\text { Log(Primary } \\
\text { school } \\
\text { personnel } \\
\text { expenditure, } \\
\text { per pupil) }\end{array}$ & $\begin{array}{l}\text { Log(Primary } \\
\text { school } \\
\text { operating } \\
\text { expenditure, } \\
\text { per pupil) }\end{array}$ & $\begin{array}{c}\text { Log(Middle } \\
\text { school } \\
\text { expenditure, per } \\
\text { pupil) }\end{array}$ & $\begin{array}{l}\text { Log(Middle } \\
\text { school } \\
\text { personnel } \\
\text { expenditure, } \\
\text { per pupil) }\end{array}$ & $\begin{array}{l}\text { Log(Middle } \\
\text { school } \\
\text { operating } \\
\text { expenditure, } \\
\text { per pupil) }\end{array}$ \\
\hline CCEC $\times$ Treat & $\begin{array}{c}-0.018^{* *} \\
(0.007)\end{array}$ & $\begin{array}{l}-0.005 \\
(0.007)\end{array}$ & $\begin{array}{c}-0.208^{* * *} \\
(0.039)\end{array}$ & $\begin{array}{c}-0.063 * * * \\
(0.009)\end{array}$ & $\begin{array}{l}-0.013 \\
(0.009)\end{array}$ & $\begin{array}{c}-0.391 * * * \\
(0.040)\end{array}$ \\
\hline Dep. Mean & 5.923 & 5.855 & 2.659 & 6.403 & 6.303 & 3.520 \\
\hline Observations & 14,330 & 13,524 & 13,524 & 14,294 & 13,528 & 13,531 \\
\hline \# of Counties & 2002 & 1995 & 1995 & 2003 & 1992 & 1993 \\
\hline County FE & YES & YES & YES & YES & YES & YES \\
\hline $\begin{array}{l}\text { Province-Year } \\
\text { FE }\end{array}$ & YES & YES & YES & YES & YES & YES \\
\hline Controls & YES & YES & YES & YES & YES & YES \\
\hline
\end{tabular}

Notes: Robust standard errors are reported in parentheses, clustered at the county level. ${ }^{* * *}$ Significant at the 1 percent level, ${ }^{* *}$ Significant at the 5 percent level, ${ }^{*}$ Significant at the 10 percent level. Constant terms and the estimated coefficients of the controls are not reported. 
Table 6: Effects on Compulsory School Enrollment Rates

\begin{tabular}{|c|c|c|c|c|c|c|}
\hline \multirow{3}{*}{ Dep. Var. } & $(1)$ & $(2)$ & (3) & (4) & (5) & (6) \\
\hline & Primary School & \multicolumn{5}{|c|}{ Middle School (\%) } \\
\hline & $(\%)$ & $\begin{array}{c}\text { Full } \\
\text { Sample }\end{array}$ & Urban males & $\begin{array}{l}\text { Urban } \\
\text { females }\end{array}$ & Rural males & Rural females \\
\hline $\mathrm{CCEC} \times$ Treat & $\begin{array}{c}0.011 \\
(0.041)\end{array}$ & $\begin{array}{c}-1.009^{* * *} \\
(0.240)\end{array}$ & $\begin{array}{l}-0.346 \\
(0.449)\end{array}$ & $\begin{array}{l}-0.524 \\
(0.372)\end{array}$ & $\begin{array}{l}-0.359 \\
(0.401)\end{array}$ & $\begin{array}{c}-1.190^{* * *} \\
(0.419)\end{array}$ \\
\hline Dep. Mean & 97.96 & 82.87 & 97.31 & 97.00 & 83.40 & 78.13 \\
\hline Observations & 18,504 & 18,488 & 13,798 & 14,278 & 18,171 & 18,224 \\
\hline \# of Clusters & 2056 & 2056 & 1904 & 1921 & 2046 & 2048 \\
\hline County FE & YES & YES & YES & YES & YES & YES \\
\hline $\begin{array}{l}\text { Province-Year } \\
\text { FE }\end{array}$ & YES & YES & YES & YES & YES & YES \\
\hline Controls & YES & YES & YES & YES & YES & YES \\
\hline
\end{tabular}

Notes: Robust standard errors are reported in parentheses, clustered at the county level. ${ }^{* * *}$ Significant at the 1 percent level, ${ }^{* *}$ Significant at the 5 percent level, ${ }^{*}$ Significant at the 10 percent level. Constant terms and the estimated coefficients of the controls are not reported. 


\section{Online Appendix}

\section{A. Additional Figures and Tables}

Figure A1: Spatial Distribution of Poor Counties Exempted for Inspection before 2001

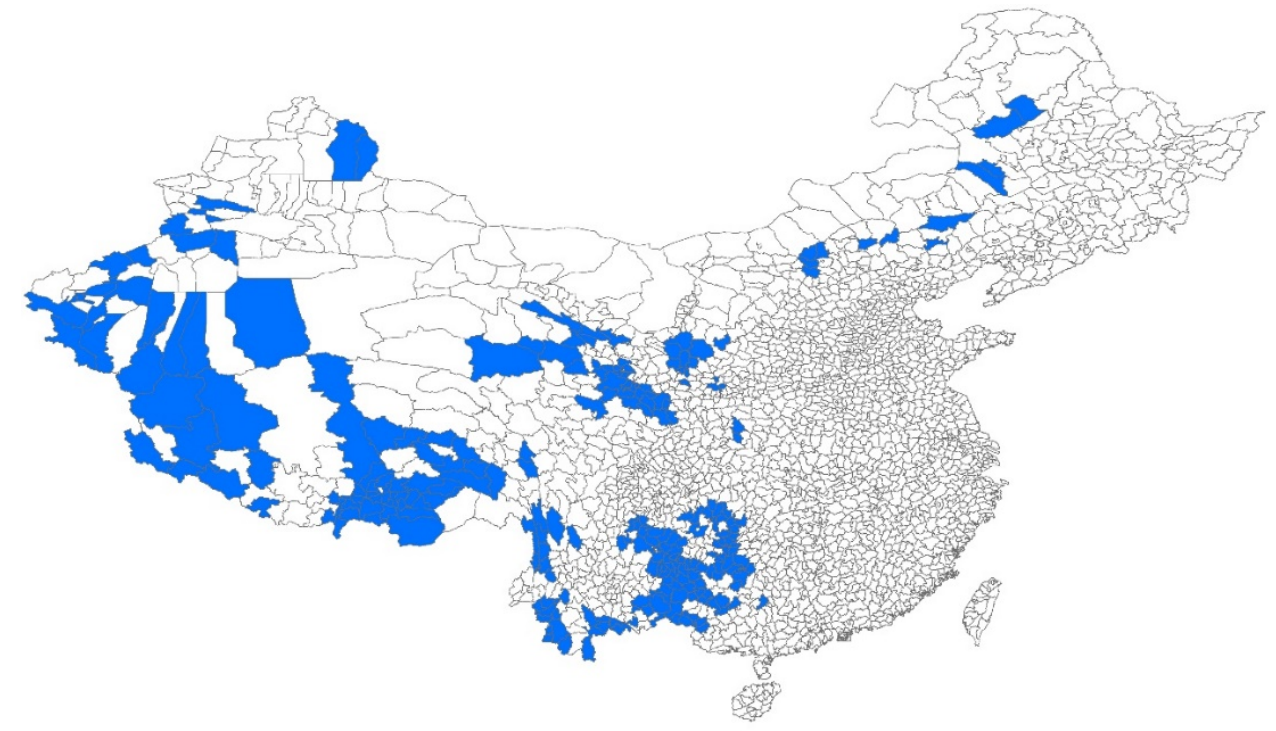

Figure A2: Correlation of Party Secretary's Tenure with Inspection Years

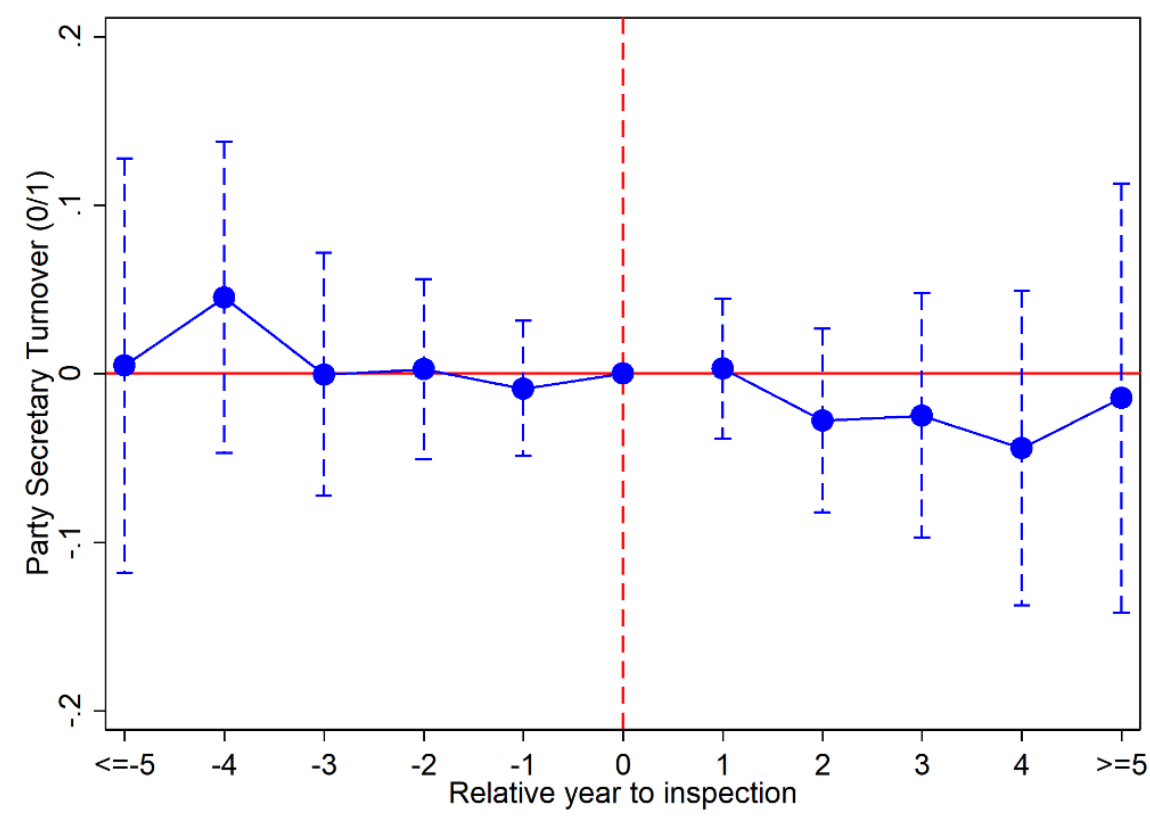

Notes: This figure presents the event study estimates for the dummy variable indicating party secretary turnover with the specification of Equation (1). The solid circle represents the estimated coefficient for each year relative to inspection year along with the $95 \%$ confidence intervals calculated by employing county-level clustered standard errors. 
Figure A3: Histogram of Time Differences between County Party Secretary's Inauguration and Inspection

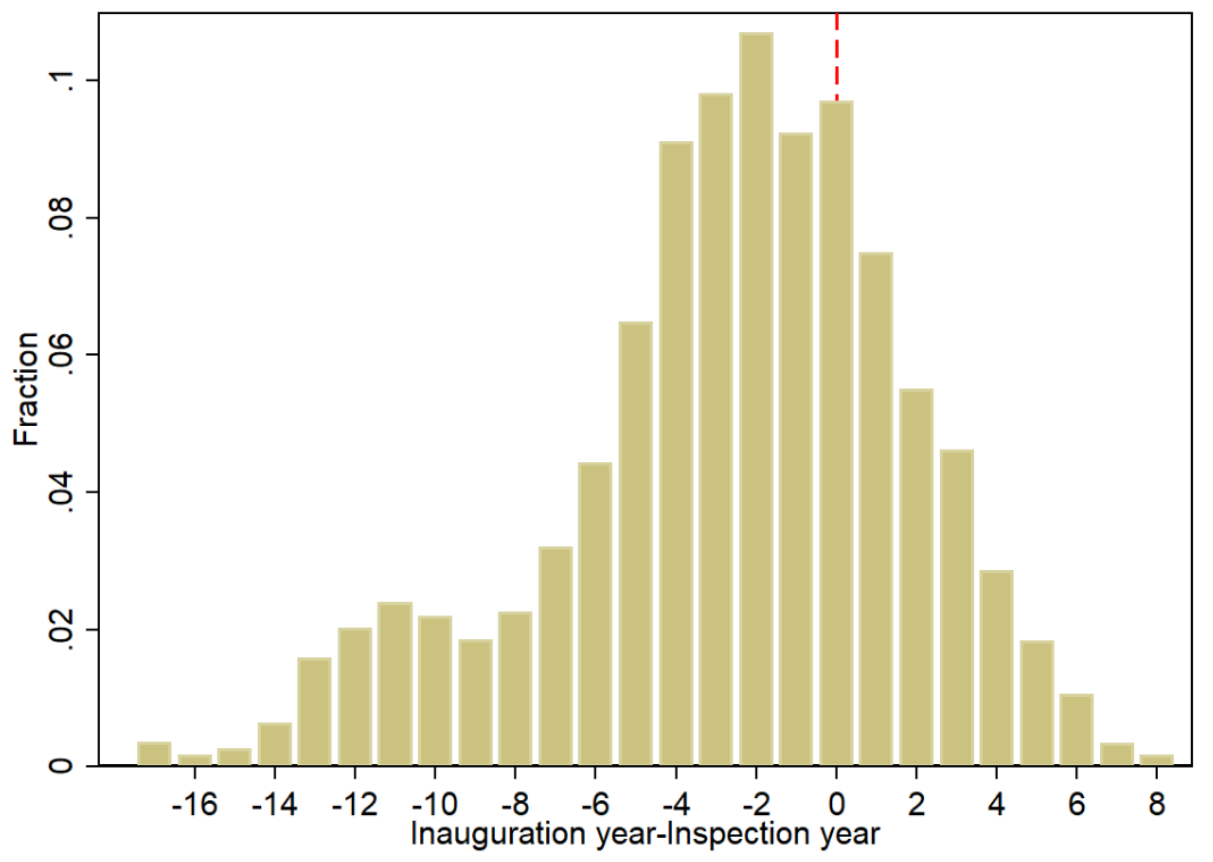


Table A1: Determinants on the Scheduled Inspection Sequence: Ordered Probit

\begin{tabular}{lc}
\hline \hline Dep. Var. & Inspection Year \\
\hline Elevation & $0.000224^{* * *}$ \\
Slope & $(7.06 \mathrm{e}-05)$ \\
& $0.0316^{*}$ \\
Proportion of citizens with middle school literacy, 1990 & $(0.0173)$ \\
& $-0.0537^{* * *}$ \\
Proportion of citizens with primary school literacy, 1990 & $(0.00466)$ \\
Illiteracy rate, 1990 & -0.00828 \\
National Poor County & $(0.0181)$ \\
& 0.0260 \\
Minority County & $(0.0177)$ \\
Province FE & $0.663 * * *$ \\
Number of Counties & $(0.0618)$ \\
\hline \hline
\end{tabular}

Notes: This table applies an ordered probit model to investigate the determinants of the scheduled inspection sequence. Robust standard errors are reported in parentheses, clustered at the county level. *** Significant at the 1 percent level, ** Significant at the 5 percent level, * Significant at the 10 percent level. Constant terms and the estimates for the cutoffs are not reported.

Table A2: CCEC Inspections and Nonrandom Missing Values

\begin{tabular}{lcccc}
\hline \hline Dep. Var. & $\begin{array}{c}(1) \\
\text { 1(Education } \\
\text { expenditure is } \\
\text { missing) }\end{array}$ & $\begin{array}{c}(2) \\
\text { 1(Fiscal education } \\
\text { expenditure is } \\
\text { missing) }\end{array}$ & $\begin{array}{c}(3) \\
\mathbf{1} \text { (Non-fiscal } \\
\text { education } \\
\text { expenditure is } \\
\text { missing) }\end{array}$ & $\begin{array}{c}\text { (4) } \\
\text { educational tax } \\
\text { rate is missing) }\end{array}$ \\
\hline CCEC $\times$ Treat & -0.003 & -0.006 & -0.000 & -0.006 \\
Dep. Mean & $(0.007)$ & $(0.007)$ & $(0.007)$ & $(0.009)$ \\
Observations & 0.167 & 0.161 & 0.174 & 0.227 \\
Number of Counties & 18,540 & 18,540 & 18,540 & 18,540 \\
County FE & 2060 & 2060 & 2060 & 2060 \\
Province-Year FE & YES & YES & YES & YES \\
Controls & YES & YES & YES & YES \\
\hline \hline
\end{tabular}

Notes: Robust standard errors are reported in parentheses, clustered at the county level. *** Significant at the 1 percent level, ** Significant at the 5 percent level, * Significant at the 10 percent level. Constant terms are not reported. 
Table A3: Controlling for Endogenous Migration

\begin{tabular}{|c|c|c|c|c|c|c|}
\hline \multirow{3}{*}{ Dep. Var. } & $(1)$ & $(2)$ & $(3)$ & $(4)$ & $(5)$ & (6) \\
\hline & Primary school & \multicolumn{5}{|c|}{ Middle school enrollment rate (\%) } \\
\hline & $\begin{array}{c}\text { enrollment rate } \\
(\%)\end{array}$ & Full sample & $\begin{array}{l}\text { Urban } \\
\text { citizen }\end{array}$ & $\begin{array}{c}\text { Rural } \\
\text { citizen }\end{array}$ & Male & Female \\
\hline \multirow[t]{2}{*}{$\mathrm{CCEC} \times$ Treat } & 0.011 & $-0.937 * * *$ & -0.165 & -0.308 & -0.203 & $-0.989 *$ \\
\hline & $(0.045)$ & $(0.298)$ & $(0.542)$ & $(0.462)$ & $(0.474)$ & $(0.512)$ \\
\hline Dep. Mean & 97.86 & 81.22 & 97.06 & 96.65 & 81.76 & 75.83 \\
\hline Observations & 18,498 & 18,467 & 12,288 & 12,617 & 17,949 & 18,061 \\
\hline \# of Clusters & 2056 & 2056 & 1778 & 1801 & 2040 & 2046 \\
\hline County FE & YES & YES & YES & YES & YES & YES \\
\hline Province-Year FE & YES & YES & YES & YES & YES & YES \\
\hline Controls & YES & YES & YES & YES & YES & YES \\
\hline
\end{tabular}

Notes: Robust standard errors are reported in parentheses, clustered at the county level. *** Significant at the 1 percent level, ** Significant at the 5 percent level, ${ }^{*}$ Significant at the 10 percent level. Constant terms and the estimated coefficients of the controls are not reported. 


\section{Appendix B: Predictions using Random Forest Model}

Figure B1: Model Fitting in 1990-1992

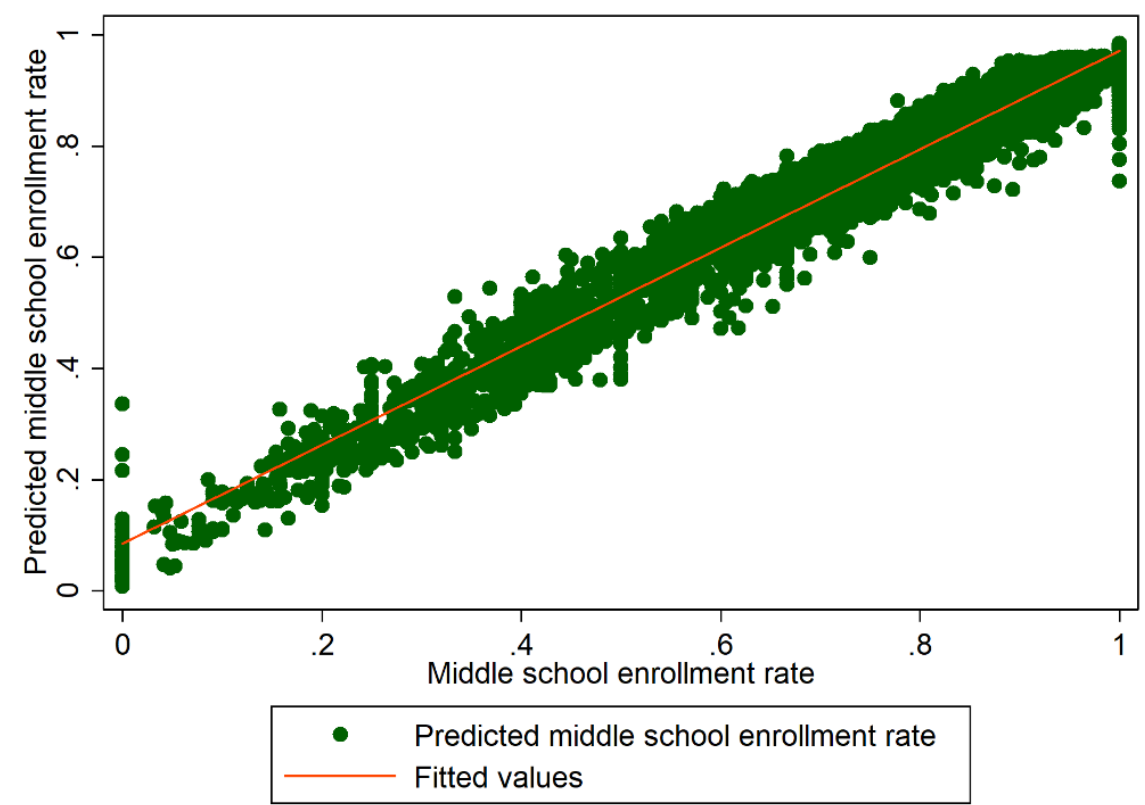

Notes: This figure documents the correlation between the predicted value of middle school enrollment rate in our random forest model and the middle school enrollment rate constructed using the 2005 population minicensus.

Figure B2: Actual and Predicted Middle School Enrollment Rates in 1990-2001

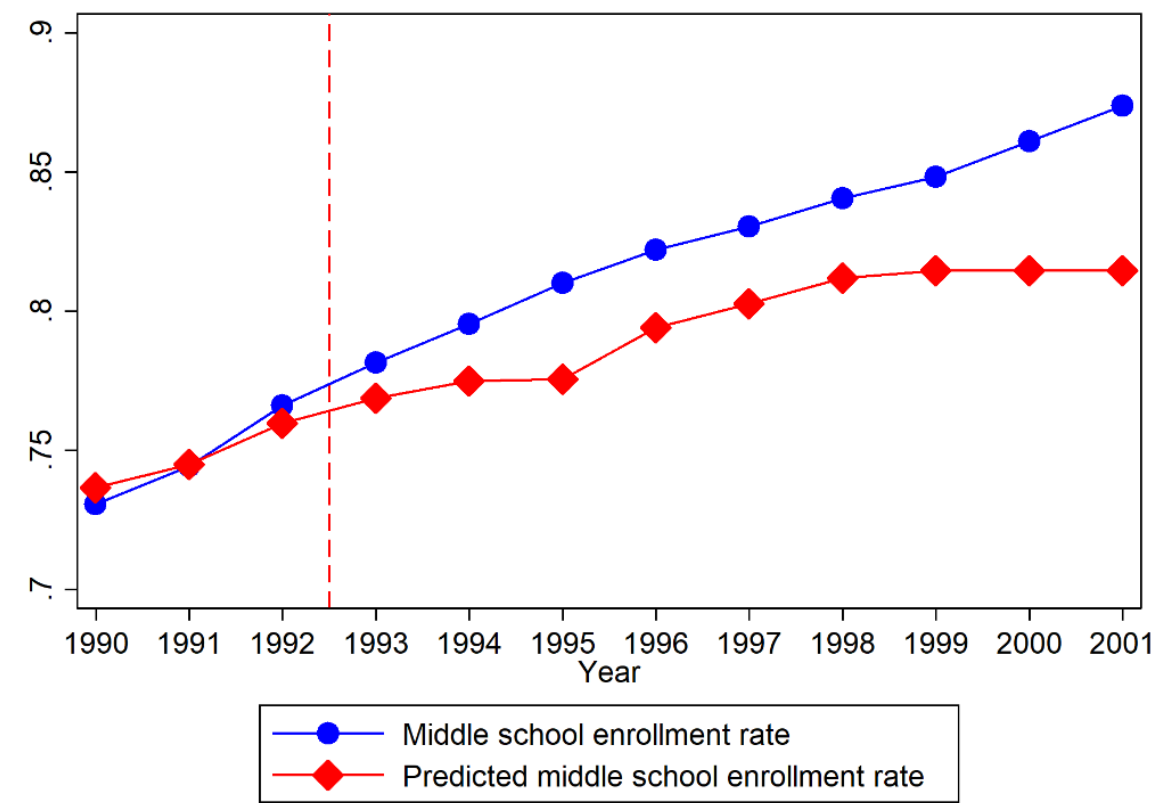

Notes: This figure plots the time patterns of China's national average middle school enrollment rate for the cohorts born in 1990-2001. The blue curve marked with circles is calculated using the 2005 mini-census data and the red curve marked with diamonds is the counterfactual prediction constructed from the random forest model. 